\title{
Nitrate aerosols today and in 2030: a global simulation including aerosols and tropospheric ozone
}

\author{
S. E. Bauer ${ }^{1,2}$, D. Koch ${ }^{1,2}$, N. Unger ${ }^{3}$, S. M. Metzger $^{4}$, D. T. Shindell ${ }^{2}$, and D. G. Streets ${ }^{5}$ \\ ${ }^{1}$ The Earth Institute at Columbia University, NY, USA \\ ${ }^{2}$ NASA Goddard Institute for Space Studies, NY, USA \\ ${ }^{3}$ University of Vermont, Burlington, USA \\ ${ }^{4}$ Max-Planck Institute for Chemistry, Mainz, Germany \\ ${ }^{5}$ Argonne National Laboratory, Argonne, IL, USA
}

Received: 5 April 2007 - Published in Atmos. Chem. Phys. Discuss.: 26 April 2007

Revised: 18 July 2007 - Accepted: 8 August 2007 - Published: 2 October 2007

\begin{abstract}
Nitrate aerosols are expected to become more important in the future atmosphere due to the expected increase in nitrate precursor emissions and the decline of ammoniumsulphate aerosols in wide regions of this planet. The GISS climate model is used in this study, including atmospheric gas- and aerosol phase chemistry to investigate current and future (2030, following the SRES A1B emission scenario) atmospheric compositions. A set of sensitivity experiments was carried out to quantify the individual impact of emissionand physical climate change on nitrate aerosol formation. We found that future nitrate aerosol loads depend most strongly on changes that may occur in the ammonia sources. Furthermore, microphysical processes that lead to aerosol mixing play a very important role in sulphate and nitrate aerosol formation. The role of nitrate aerosols as climate change driver is analyzed and set in perspective to other aerosol and ozone forcings under pre-industrial, present day and future conditions. In the near future, year 2030, ammonium nitrate radiative forcing is about $-0.14 \mathrm{~W} / \mathrm{m}^{2}$ and contributes roughly $10 \%$ of the net aerosol and ozone forcing. The present day nitrate and pre-industrial nitrate forcings are -0.11 and $-0.05 \mathrm{~W} / \mathrm{m}^{2}$, respectively. The steady increase of nitrate aerosols since industrialization increases its role as a non greenhouse gas forcing agent. However, this impact is still small compared to greenhouse gas forcings, therefore the main role nitrate will play in the future atmosphere is as an air pollutant, with annual mean near surface air concentrations, in the fine particle mode, rising above $3 \mu \mathrm{g} / \mathrm{m}^{3}$ in China and therefore reaching pollution levels, like sulphate aerosols.
\end{abstract}

Correspondence to: S. E. Bauer

(sbauer@giss.nasa.gov)

\section{Introduction}

Nitrate aerosols are chemically formed in the atmosphere and their main precursor species are ammonia and nitric acid. Ammonia and nitric oxides, which is a precursor of nitric acid, have a long list of anthropogenic and natural sources. The major identified sources of ammonia include excreta from domestic and wild animals, synthetic fertilizers, oceans, biomass burning, crops, human populations and pets, soils, industrial processes and fossil fuels (Bouwman et al., 1997). Typical sources of nitric oxides are fossil fuel combustion, soils, biomass burning and lightning.

A series of modeling studies (Adams et al., 2001; Metzger et al., 2002b,a; Liao et al., 2003; Rodriguez and Dabdub, 2004; Feng and Penner, 2007) identified nitrate and ammonium as significant anthropogenic sources of aerosol load and their radiative effects (Adams et al., 2001; Jacobson, 2001; Liao et al., 2004), but currently most global aerosol models still exclude ammonium-nitrate when the direct aerosol radiative forcing is studied (Schulz et al., 2006; Textor et al., 2006; Kinne et al., 2006). Even so, global model studies (Adams et al., 2001; Liao et al., 2006; Liao and Seinfeld, 2005) have demonstrated that rapid increases in nitrogen emissions could produce enough nitrate aerosol to offset the expected decline in sulphate forcing by 2100 , for the extreme IPCC A2 scenario. Furthermore, recent studies indicate that the condensation of nitric acid on aerosol particles may enhance aerosol activation to cloud droplets by contributing soluble material to the particle surface and elevating the water uptake and growth of aerosol particles (Kulmala et al., 1995, 1998; Goodman et al., 2000). Thus full consideration of aerosol composition including hygroscopic components like nitrate and ammonium could be important in the calculation of aerosol indirect forcing.

Published by Copernicus Publications on behalf of the European Geosciences Union. 
The formation of nitrate and ammonium aerosol also affects tropospheric chemistry. Nitrate and ammonium aerosols provide additional particle surfaces for scattering incoming ultraviolet solar radiation (Liao et al., 2003) and will thus perturb photochemical oxidant production by altering photolysis frequencies. Moreover, nitrate aerosol is formed through heterogeneous reactions of nitrogen radicals such as $\mathrm{N}_{2} \mathrm{O}_{5}, \mathrm{NO}_{3}$, and $\mathrm{HNO}_{3}$ on aerosol surfaces (Dentener et al., 1996; Jacob, 2000; Bauer et al., 2004, 2007). These heterogeneous chemical processes can alter tropospheric chemistry; for example the global tropospheric ozone mass can be reduced by $5 \%$ through the interactions of gas-phase species with mineral dust aerosols. Meanwhile, insoluble atmospheric mineral dust lifetime and load are reduced as coating by hydrophilic air pollution increases its precipitation scavenging (Bauer and Koch, 2005; Bauer et al., 2007). In order to study the effects of nitrate and ammonium aerosol on radiative processes and gas-phase chemistry, one must first consider the partitioning of semi-volatile nitrate and ammonium between the gas and aerosol phases. Several equilibrium models (EQMs) were developed to predict the phase equilibrium behavior of multicomponent aerosols and their gas-phase precursors in the atmosphere - all involving at least the $\mathrm{NH}_{3} / \mathrm{HNO}_{3} / \mathrm{NH}_{4} \mathrm{NO}_{3}$ gas-aerosol system. Stateof-the-art EQMs include ADDEM (Topping et al., 2005a,b), AIM (Clegg et al., 1992; Clegg and Pitzer, 1992; Clegg et al., 1998b,a), EQSAM (Metzger et al., 2002b), EQSAM2 (Metzger et al., 2006; Trebs et al., 2005), EQSAM3 (Metzger and Lelieveld, 2007), EQUISOLV (Jacobson et al., 1996), EQUISOLVII (Jacobson, 1999), GFEMN (Ansari and Pandis, 1999), ISORROPIA (Nenes et al., 1998; Pilinis et al., 2000), MARS-A (Binkowski and Shankar, 1995), MESA (Zaveri et al., 2005), SCAPE (Kim et al., 1993a,b; Kim and Seinfeld, 1995), SCAPE2 (Meng et al., 1995), UHAERO (Amundson et al., 2006), older EQMs include EQUIL (Bassett and Seinfeld, 1983), KEQUIL (Bassett and Seinfeld, 1984), MARS (Saxena et al., 1986), and SEQUILIB (Pilinis and Seinfeld, 1987). Some of these models have been compared in Zhang et al. (2000); Amundson et al. (2006); Metzger et al. (2006); Metzger and Lelieveld (2007).

However, the problem with most of these models is that they are extremely computationally expensive. Since the GISS Genereral Circulation Model (GCM) is designed for long climate applications, computational efficiency is crucial. Therefore, we have chosen the efficient gas/aerosol partitioning model EQSAM (Equilibrium Simplified Aerosol Model). The approach used for EQSAM is based on the relationship between activity coefficients and relative humidity (Metzger et al., 2002b, 2006). This relationship allows parameterization of the relevant nonideal solution properties, which is sufficiently accurate for global modeling (Metzger et al., 2002a). Although EQSAM chemistry is parameterized, the thermodynamic framework is based on the same assumptions used by other equilibrium models.
In this study the GISS GCM is employed, including coupled gas and aerosol phase chemistry modules. A brief summary of nitrate chemistry is given in Sect. 2. The GCM, the emission scenario and the model set up are described in Sect. 3. Current day nitrate concentrations to observations are presented in Sect. 4, followed by a comparison of present day and future nitrate and sulphate distributions in Sect. 5 . The sensitivity studies, regarding the impact of changes in individual emission sources and physical climate change are presented in Sect. 6. And the radiative forcing contributions of the single aerosols and ozone under past, present and future conditions are shown in Sect. 7. Conclusions are presented in Sect. 8.

\section{Nitrate chemistry}

The formation of ammonium nitrate aerosol depends on the thermodynamic state of its precursor and depends strongly on the environmental conditions. Gaseous ammonia and nitric acid react in the atmosphere to form aerosol ammonium nitrate, $\mathrm{NH}_{4} \mathrm{NO}_{3}$.

$\mathrm{NH}_{3}(\mathrm{~g})+\mathrm{HNO}_{3}(\mathrm{~g}) \rightleftharpoons \mathrm{NH}_{4} \mathrm{NO}_{3}(\mathrm{~s})$

Ammonium nitrate is formed in areas characterized by high ammonia and nitric acid conditions and low sulphate conditions. Depending on the ambient relative humidity $(\mathrm{RH})$, ammonium nitrate may exist as a solid or as an aqueous solution of $\mathrm{NH}_{4}^{+}$and $\mathrm{NO}_{3}^{-}$. Equilibrium concentrations of gaseous $\mathrm{NH}_{3}$ and $\mathrm{HNO}_{3}$, and the resulting concentration of $\mathrm{NH}_{4} \mathrm{NO}_{3}$ is calculated by thermodynamical principals, requiring the ambient RH and temperature. At low temperatures the equilibrium of the system shifts towards the aerosol phase. At low $\mathrm{RH}$ conditions $\mathrm{NH}_{4} \mathrm{NO}_{3}$ is solid, and at $\mathrm{RH}$ conditions above the deliquescence, $\mathrm{NH}_{4} \mathrm{NO}_{3}$ will be found in the aqueous state.

$\mathrm{NH}_{3}(\mathrm{~g})+\mathrm{HNO}_{3}(\mathrm{~g}) \rightleftharpoons \mathrm{NH}_{4}^{+}(\mathrm{aq})+\mathrm{NO}_{3}^{-}(\mathrm{aq})$

For a given temperature the solution of the equilibrium equation requires the calculation of the corresponding molalities. These concentrations depend not only on the aerosol nitrate and ammonium but also on the amount of water in the aerosol phase. Therefore calculations of the aerosol solution composition requires estimation of the aerosol water content. The presence of water allows $\mathrm{NH}_{4} \mathrm{NO}_{3}$ to dissolve in the liquid aerosol particles and increases its aerosol concentration. Ammonium and nitrate will exist in the aerosol phase only if there is enough ammonia and nitric acid present to saturate the gas phase.

Sulfuric acid plays an important role in nitrate aerosol formation. Sulfuric acid possesses an extremely low vapor pressure. Furthermore $\left(\mathrm{NH}_{4}\right)_{2} \mathrm{SO}_{4}$ is the preferred form of sulphate, so each mole of sulphate will remove 2 moles of ammonia from the gas phase. 
Therefore two regimes are important for nitrate formation: the ammonia-rich and the ammonia-poor case.

Ammonia-poor: In this case there is insufficient $\mathrm{NH}_{3}$ to neutralize the available sulphate. Thus the aerosol phase will be acidic. The vapor pressure of $\mathrm{NH}_{3}$ will be low, and the sulphate will tend to drive the nitrate to the gas phase. Since the $\mathrm{NH}_{3}$ partial pressure will be low, the $\mathrm{NH}_{3}-\mathrm{HNO}_{3}$ partial pressure product will also be low so ammonium nitrate levels will be low or zero.

$\mathrm{NH}_{3}+\mathrm{H}_{2} \mathrm{SO}_{4}(\mathrm{~g}) \rightleftharpoons\left(\mathrm{NH}_{4}\right) \mathrm{HSO}_{4}$

$\mathrm{NH}_{3}+\left(\mathrm{NH}_{4}\right) \mathrm{H}_{2} \mathrm{SO}_{4}(\mathrm{~g}) \rightleftharpoons\left(\mathrm{NH}_{4}\right)_{2} \mathrm{SO}_{4}$

Ammonia-rich: In this case there is excess ammonia, so that the aerosol phase will be neutralized to a large extent. The ammonia that does not react with sulphate will be available to react with nitrate to produce $\mathrm{NH}_{4} \mathrm{NO}_{3}$.

Competition between sulphate and nitrate for available ammonia results in rather complicated system behavior. The reduction of sulphate results in partial replacement of reduced aerosol mass by available nitric acid. The sulphate decrease frees up ammonia to react with nitric acid and to transfer it to the aerosol phase.

Heterogeneous reactions of gaseous species with coarse aerosol species, like mineral dust and sea salt particles, have an important impact on nitrate aerosol formation. For example the reaction of nitric acid with calcium carbonate can take place when alkaline material is present in the mineral dust:

$\mathrm{CaCO}_{3}+\mathrm{HNO}_{3} \rightarrow \mathrm{Ca}^{2+} \mathrm{NO}_{3}^{-}+\mathrm{HCO}_{3}^{-}$

Once $\mathrm{HNO}_{3}$ is formed, it is most likely captured by coarse mode sea-salt and dust particles, leading to a depletion of aerosol nitrate in the fine mode. During the night when ammonia is present in excess, ammonium nitrate can be formed; however, since this salt is thermodynamically not stable, it can evaporate during the day whereby the aerosol precursor gases $\mathrm{NH}_{3}$ and $\mathrm{HNO}_{3}$ are likely to condense on preexisting and larger aerosol particles (e.g. Wexler and Seinfeld, 1990). As a consequence, some anthropogenic air pollutants may not be confined to the fine aerosol mode but rather interact with larger particles which might be of natural origin such as sea salt and mineral dust aerosol.

\section{Model description}

The Goddard Institute for Space Studies (GISS) general circulation model (GCM) version modelE (Schmidt et al., 2006; Hansen et al., 2005) is employed for this study, with fully interactive tropospheric chemistry and aerosol modules. We use 23 vertical layers (model top in the mesosphere at $0.01 \mathrm{mb}$ ) and $4^{\circ} \times 5^{\circ}$ horizontal resolution. The tropospheric gas-phase mechanism (Shindell et al., 2003) represents background $\mathrm{HO}_{\mathrm{x}}-\mathrm{NO}_{\mathrm{x}}-\mathrm{O}_{\mathrm{x}}-\mathrm{CO}-\mathrm{CH}_{4}$ chemistry as well as peroxyacetylnitrates, hydrocarbon families, and isoprene based on
32 species and 77 reactions. Methane concentrations are prescribed according to the used scenario. The thermodynamic gas-aerosol equilibrium model (EQSAM2) (Metzger et al., 2002b,a, 2006) is implemented in the climate model to simulate ammonium nitrate aerosols. We use the latest version EQSAM2, to calculate the gas/liquid/solid partitioning of the $\mathrm{H}_{2} \mathrm{SO}_{4} / \mathrm{HSO}_{4}^{-} / \mathrm{SO}_{4}^{2-} \mathrm{HNO}_{3} / \mathrm{NO}_{3}^{-}-\mathrm{NH}_{3} / \mathrm{NH}_{4}^{+}$$\mathrm{HCL} / \mathrm{CL}^{-}-\mathrm{Na}^{+} \mathrm{Ca}^{2+}-\mathrm{Mg}^{2+}-\mathrm{K}^{+}-\mathrm{H}_{2} \mathrm{O}$ system. Further aerosol modules applied in this study include sulphate (Koch et al., 1999; Koch and Hansen, 2005), carbonaceous aerosols (Koch et al., 2006, 2007a), sea salt (Koch and Hansen, 2005), mineral dust (Miller et al., 2006) and heterogeneous sulphate and nitrate production on mineral dust surfaces (Bauer and Koch, 2005; Bauer et al., 2007, 2004).

Aerosols are represented in a bulk scheme. Aerosol mass is carried in the model for fine mode sulfate and nitrate using one bin for each component, assuming a log-normal size distribution and an effective radius of 0.2 and $0.3 \mu \mathrm{m}$, respectively. Black and organic aerosols are each carried in two different bins, assuming the same size per specie of $0.1 \mu \mathrm{m}$ for $\mathrm{BC}$ and $0.3 \mu \mathrm{m}$ for $\mathrm{OC}$, but different solubility, in order to account for aerosol aging. Two size bins are used to represent sea salt aerosols, with effective radii of 0.44 and $5 \mu \mathrm{m}$. Mineral dust aerosols are tracked in four size bins, spanning over the range of 0.1 to $10 \mu \mathrm{m}$, with effective radii of, $0.46,1.47$, 2.94 and $5.88 \mu \mathrm{m}$. The sulphate and nitrate coating amounts, that are deposited on the dust surfaces by condensation of the precursor species $\mathrm{HNO}_{3}, \mathrm{O}_{3}, \mathrm{H}_{2} \mathrm{SO}_{4}$ onto the dust surfaces are tracked in the model for each dust size bin.

The aerosols are approximated as externally mixed for radiative calculations. The radiative effect of nitrate and sulphate material that is present in the coarse mode, due to it's attachment to mineral dust particles, can be assumed negligible, because the optical properties of the mixed particle are nearly identical to an uncoated mineral dust particle (Bauer et al., 2007). The effect of humidity on sulphate, nitrate and OC aerosol sizes substantially increases the aerosol optical depths ((Koch et al., 2006); A. Lacis web data base at http:gacp.giss.nasa.gov/data_sets/lacis/database.html.)

The uptake of nitrate or nitric acid into sea salt particles is not considered in this simulation, because our size resolution of two size bins to represent sea salt aerosols is to coarse to calculate an appropriate estimate of the available surface area of sea salt aerosols. Liao et al. (2003) had to expand her sea salt bins into 11 bins to get an reasonable estimate. We are aware that neglecting this surface reaction might underestimate nitrate in the coarse fraction of our simulations. However, mineral cations that originate form sea salt and mineral dust (i.e. $\mathrm{Na}^{+}, \mathrm{Ca}^{2+}, \mathrm{Mg}^{2+}, \mathrm{K}^{+}$) influence nitrate formation (Metzger et al., 2006). 
Table 1. Anthropogenic and natural trace gas emissions.

\begin{tabular}{lccl}
\hline & 2000 & 2030 & $\Delta[\%]$ \\
\hline $\begin{array}{l}\mathrm{NO}_{\mathrm{x}}[\mathrm{Tg} \mathrm{N} / \mathrm{yr}] \\
\text { natural }\end{array}$ & 16.3 & 16.5 & +1 \\
anthropogenic & 29.9 & 53.5 & +79 \\
$\mathrm{NH}_{3}[\mathrm{TgN} / \mathrm{yr}]$ & & & \\
natural & 14.4 & 14.4 & - \\
anthropogenic & 39.7 & 58.1 & +46 \\
$\mathrm{SO}_{2}[\mathrm{Tg} \mathrm{S} / \mathrm{yr}]$ & & & \\
natural & 11.8 & 11.9 & +1 \\
anthropogenic & 72.1 & 96.0 & +33 \\
$\mathrm{CO}[\mathrm{Tg} / \mathrm{yr}]$ & & & \\
& 846.0 & 1031.5 & +22 \\
$\mathrm{BC}[\mathrm{Tg} / \mathrm{yr}]$ & & & \\
industrial & 4.5 & 3.6 & -19 \\
biomass & 3.7 & 3.4 & -9 \\
$\begin{array}{l}\mathrm{OC}[\mathrm{Tg} / \mathrm{yr}] \\
\text { industrial }\end{array}$ & 11.4 & 7.3 & -36 \\
biomass & 30.6 & 27.8 & -9 \\
terpene & 16.6 & 16.6 & - \\
\hline
\end{tabular}

\subsection{Emissions}

\section{Anthropogenic emissions}

For present day conditions, the trace gas emissions are based on the anthropogenic emissions for 1995 from the Emissions Database for Global Atmospheric Research (EDGAR3.2) (Olivier and Berdowski, 2001). The 2030 future scenario is based on the A1B projection of the IPCC SRES model (Nakicenovic et al., 2000). The A1B scenario features rapid economic growth with a balance between fossil fuel intensive and renewable energy sources. The EDGAR3.2 and the future projection provide emissions for carbon-monoxide $(\mathrm{CO})$, Nitrogen Oxides $\left(\mathrm{NO}_{\mathrm{x}}\right)$, non-methane volatile organic compounds (NMVOC), methane $\left(\mathrm{CH}_{4}\right)$, sulfur dioxide (SO2) and ammonia $\left(\mathrm{NH}_{3}\right)$ (Bouwman et al., 1997). Black (BC) and organic carbon (OC) emissions for present day conditions are Bond et al. (2004) with the A1B future from Streets et al. (2004).

\section{Natural emission}

The emissions of the natural aerosols, sea salt and mineral dust, as well as dimethylsulfide (DMS) are calculated interactively in the model, depending on the wind speed and the surface conditions. In the current simulation $1748 \mathrm{Tg}$ mineral dust and $1859 \mathrm{Tg}$ sea salt are emitted under present climate conditions, with negligible change for future climate conditions. Gaseous emissions of dimethylsulfide (DMS) and isoprene are parameterized after Koch et al. (2007b) and Guenther et al. (1995). Natural $\mathrm{NO}_{\mathrm{x}}$ emissions from lightning are parameterized as described in Price et al. (1997). Biomass burning emissions are included in the EDGAR inventory and the A1B projection are given by Streets et al. (2004). Natural $\mathrm{OM}$ emissions are assumed to be derived from terpene emissions (Guenther et al., 1995), with a 10\% production rate.

\subsubsection{Emission distributions}

Anthropogenic emission fluxes are expected to be significantly altered within the next 30 years. Projected emission increases for $\mathrm{NH}_{3}, \mathrm{NO}_{\mathrm{x}}, \mathrm{SO}_{2}, \mathrm{VOCs}, \mathrm{CO}$, and decreases for $\mathrm{BC}$ and $\mathrm{OC}$ between the present and 2030 are presented in Table 1 and the horizontal distributions are given in Fig. 1. The pattern for each individual precursor species can look very different, because different activities are associated with individual sources, for example, transportation, biomass burning, agriculture, etc., which are expected to evolve differently in different countries. For example ammonia $\left(\mathrm{NH}_{3}\right)$ emissions and biomass burning emissions have anthropogenic and natural contributions. The natural contributions from oceanic, and untreated land sources are assumed to stay unchanged, whereas emissions related to industry, humans, fertilizers, crops, domestic animals, fossil fuel and bio fuel change between 2000 and 2030. The largest source of $\mathrm{NH}_{3}$ emissions is associated with livestock husbandry and the agricultural use of fertilizers. The largest increase in $\mathrm{NH}_{3}$ sources is predicted to occur in India and Asia. The only area where small decreases are expected is Northern Europe. A similar pattern in the predicted change of $\mathrm{NO}_{\mathrm{x}}, \mathrm{SO}_{2}$ and VOCs can be found in Fig. 1, because these emissions are mostly associated with energy consumption that can be split up in sources, like transportation, power plants, residential and biomass burning. This may lead to a general decrease of emissions in Europe, Japan, Australia and most of North America, except Mexico. Largest increases are expected for India, Asia, Coastal Africa and South and Middle America.

The carbonaceous emissions, black and organic carbon also may shift. Technology implementation and fuel switching may lead to less carbonaceous emissions in the United States of America, Europe, India and Asia (Streets et al., 2004). Reduced biomass burning may lead to less emissions in Sub-Sahara Africa.

Table 1 gives the global annual emission fluxes for the years 2000 and 2030 and the percentage change between those years. Although there are large decreases in current industrial countries, the annual trace gas emissions are expected to increase globally (see Table 1) for all noncarbonaceous species. The largest percent increase is assumed to be $\mathrm{NO}_{\mathrm{x}}$ emissions, which increase by $79 \%$ in our inventory. Carbonaceous emissions are the only emissions that are expected to decrease globally.

\subsection{Model experimental setup}

The model simulation duration is 6 years and the average over the last 5 years are presented in this paper. Present 

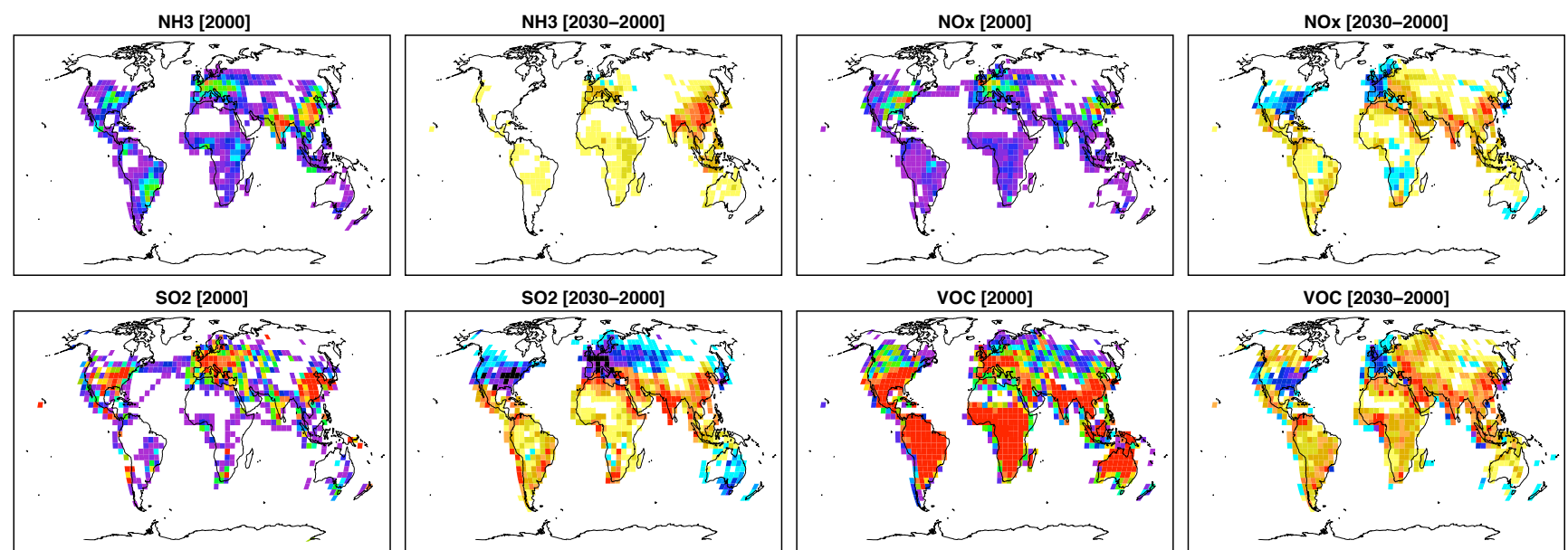

SO2 [2030-2000]
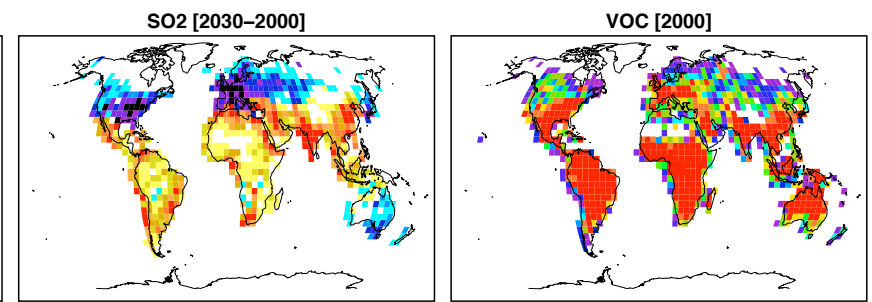

VOC [2030-2000]
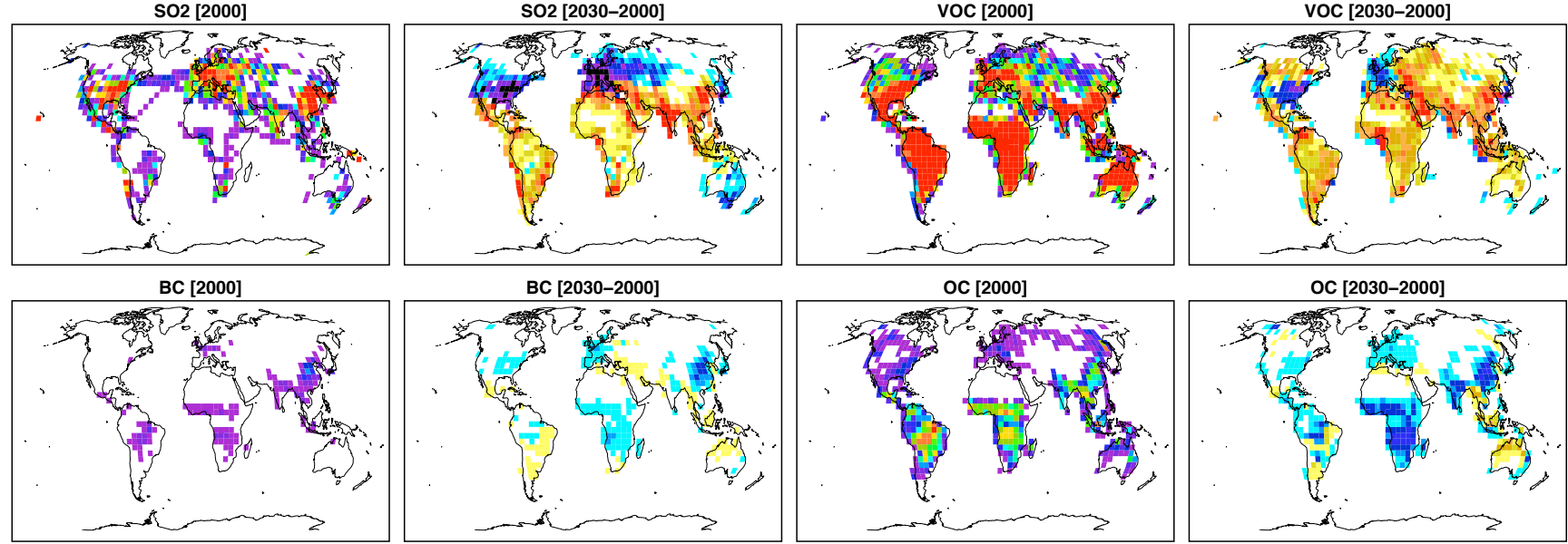

OC [2030-2000]

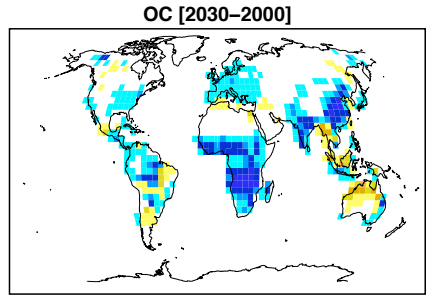

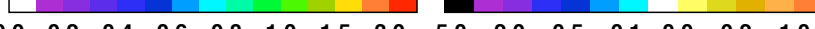

$\begin{array}{lllllllllllllll}0.0 & 0.2 & 0.4 & 0.6 & 0.8 & 1.0 & 1.5 & 3.0 & -5.0 & -2.0 & -0.5 & -0.1 & 0.0 & 0.2 & 1.0\end{array}$

Fig. 1. Annual mean emission flux $\left[\mathrm{g} / \mathrm{m}^{2} / \mathrm{yr}\right]$ for the year 2000 and the difference between the year 2030 and $2000, \mathrm{of}_{3}, \mathrm{NO}_{\mathrm{x}}, \mathrm{SO}_{2}$, VOC, black carbon, and organic carbon.

day and future climate conditions are driven by sea surface temperature and sea ice conditions from a transient model run using the coupled atmosphere-ocean mode Russell et al. (2000). That simulation assumes an $0.5 \%$ increase of $\mathrm{CO}_{2}$ concentrations and leads to an increase in global mean sea surface temperature of $0.78^{\circ} \mathrm{C}$ and to a slightly more humid environment. The model configuration in this study, except for the part involving nitrate and dust aerosols, is similar as in Unger et al. (2006), where the physical climate change is discussed in greater detail.

Two experiments are carried out under current climate conditions: A baseline experiment (CTR-00) using current emission levels and an experiment using current climate but future emissions (E30-00). In order to understand future nitrate concentrations, a series of sensitivity studies is carried out where either the climate or only one emission species is altered. Several experiments are run for future climate conditions: A baseline experiment, using the appropriate future emissions (CTR-30), three experiments where one of the following emissions, $\mathrm{SO} 2(\mathrm{SO} 2-00), \mathrm{NO}_{\mathrm{x}}\left(\mathrm{NO}_{\mathrm{x}}-00\right)$ or $\mathrm{NH} 3$ (NH3-00) was set respectively to its 2000 values, and one experiment where no heterogeneous interactions on mineral dust surfaces took place (HET-30).

\section{Current aerosol evalulation}

Evaluating a coarse GCM simulation of nitrate aerosols with observations is a fairly difficult task, because the complex chemistry and the short lifetime of nitrate aerosols can lead to large gradients in concentrations in small areas, that cannot be represented within a coarse resolution model, where one single grid box covers the domain of $400 \times 500 \mathrm{~km}$. Nevertheless, to demonstrate that our model is able to represent the general characteristics of present day ammonium-nitrate concentrations, the following data sets are used for evaluation: Surface measurements of the European EMEP, the North American IMPROVE and the global Prospero (Prospero, 1995) network, and vertical profiles from various measurement campaigns around the world, carried out between 1994 until 2004.

Figure 2 presents the models annual mean surface nitrate mass overlaid by the observations from the EMEP and IMPROVE networks and from D. Savoie and J. Prospero (personal communication, November 1999). If not otherwise noticed, the total nitrate aerosol mass, thus the sum of ammonium nitrate and nitrate aerosol is compared to the bulk nitrate mass observations. In Fig. 2 it is clearly visible, that the model underestimates nitrate especially in the remote areas when heterogeneous dust chemistry is not included in the 

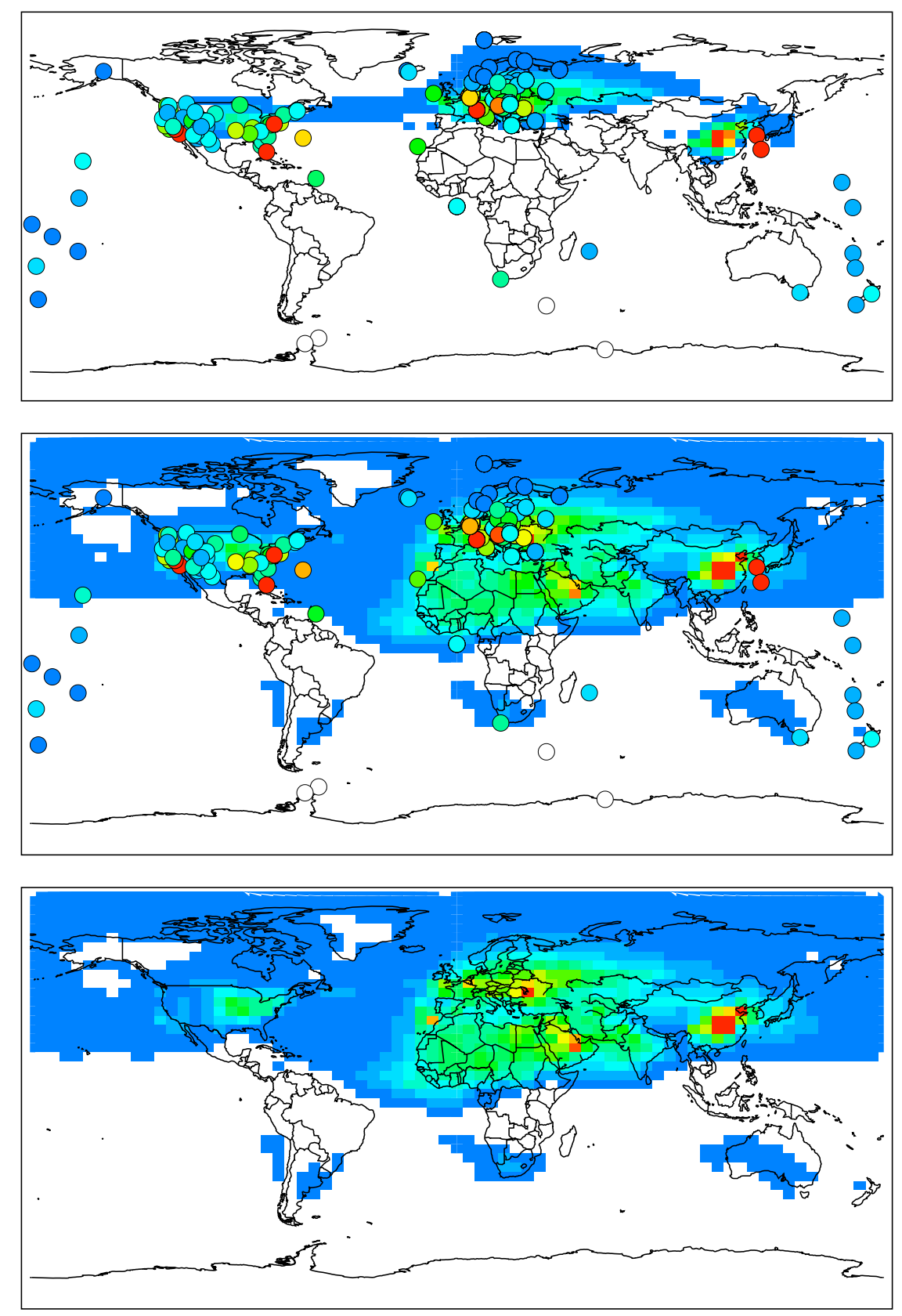

\section{$\begin{array}{llllllllll}0.0 & 0.2 & 0.3 & 0.4 & 0.6 & 0.7 & 0.9 & 1.0 & 1.2 & 1.4\end{array}$}

Fig. 2. Annual mean surface concentrations of total nitrate aerosol mass. The filled circles show measurements as observed by the EMEP, IMPROVE and the Prospero network. The upper panel shows fine mode ammonium-nitrate aerosol only, the middle panel the sum of fine and coarse mode nitrate, and the lower panel shows fine and coarse mode nitrate, but excluding the observations. Units are in $\left[\mu \mathrm{g} \mathrm{m}^{-3}\right]$.

model simulation. Overall the simulation matches the observations on the global scale, but the model underestimates the observations in certain regions. Unfortunately, we only had two surface observations off the coast of China available, to evaluate East Asian air pollution. The model shows a pollution plume over North East China, but much smaller concentrations downwind of this area, therefore we conclude that the entire East Asian nitrate mass is underestimated in the 

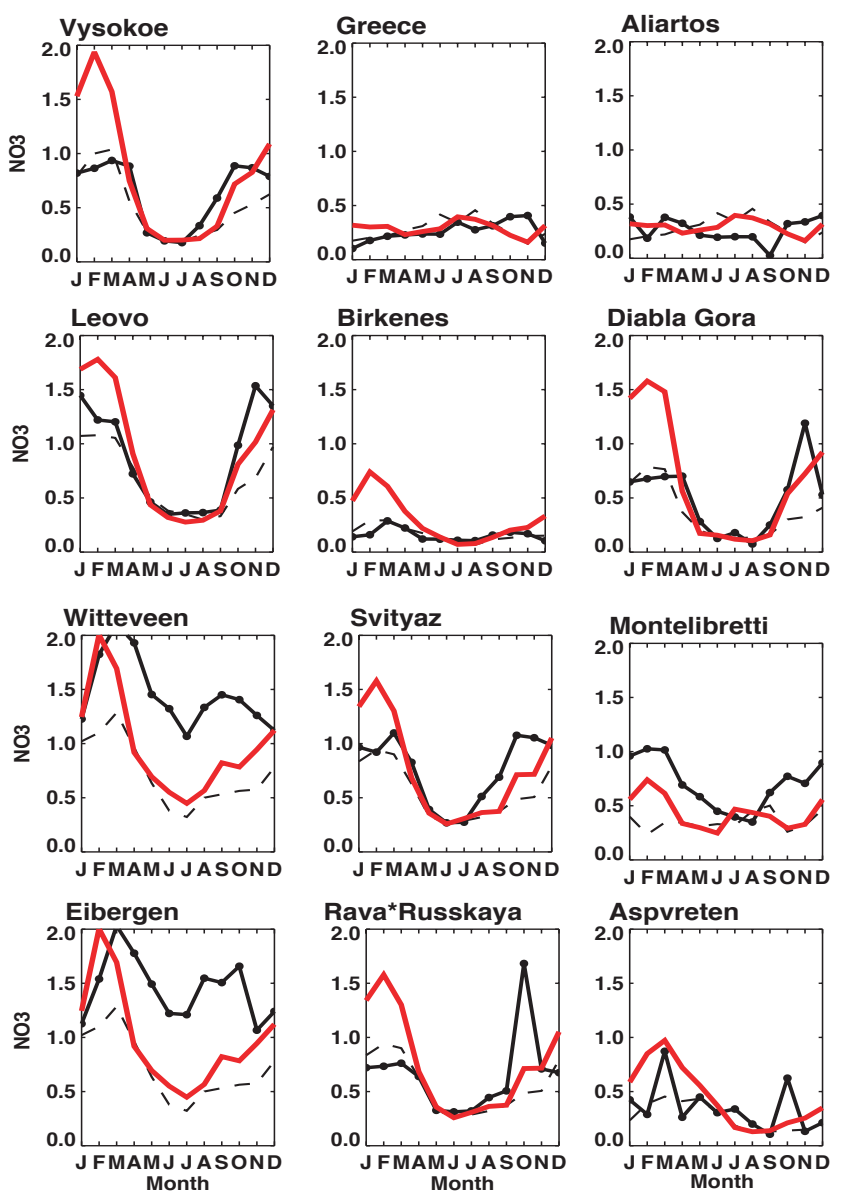

Month

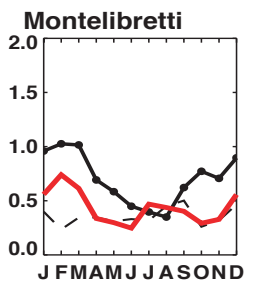

Aspvreten

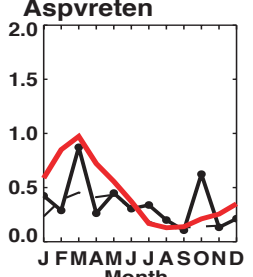

Month
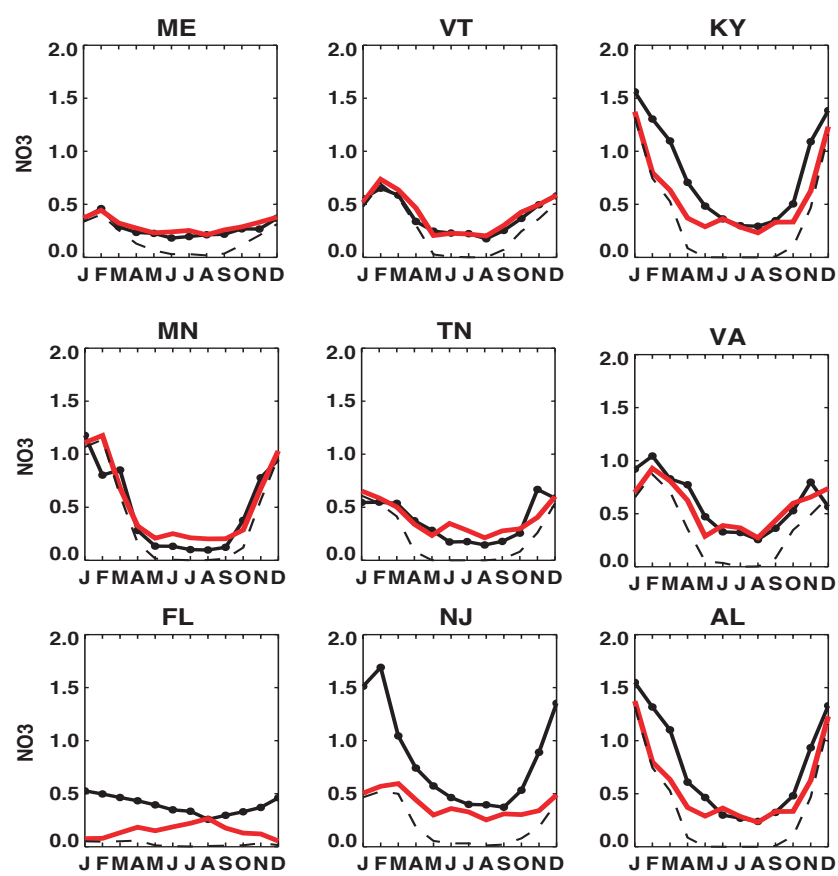

AL
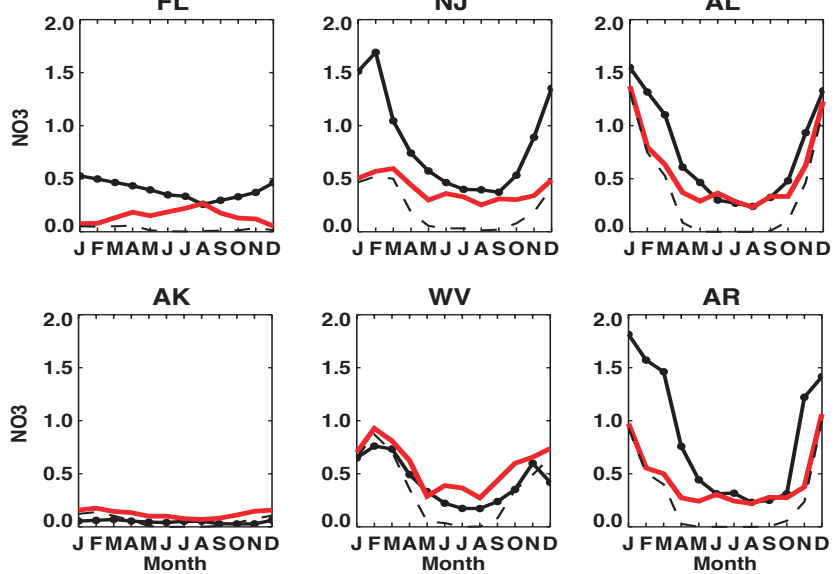

Fig. 4. Monthly mean total nitrate concentrations (red line), modelled fine mode nitrate only (dashed line) and observations from the IMPROVE network (black dashed line), shown for a selection of representative IMPROVE stations. Values are shown for the year 2000 in $\left[\mu \mathrm{g} \mathrm{m}^{-3}\right]$.

model. This conclusion is confirmed by the comparison with aircraft data (see Fig. 5) from the ACE ASIA (Huebert et al., 2003) measurement campaign, where the model underestimates the observed values by an order of magnitude in the planetary boundary layer. These very large differences between measurement and simulations can only be explained by dramatic underestimation of the emission data in East Asia. Similar results were seen by a multi-model comparison to CO observations (Shindell et al., 2006). Hence we suggest that there may be a general bias in Asian emissions spanning over multiple species.

A much smaller difference of about $0.2 \mu \mathrm{g} / \mathrm{m}^{3}$ appears over the South Pacific. We speculate that in this region, surface reactions between nitrate and sea salt particles are of importance, a reaction that is missing in this model run. The dense European network shows large gradients in nitrate mass that the model has difficulties to represent, but overall the model represents European nitrate mass very well, except

some high pollution measurements that exceed $1.5 \mu \mathrm{g} / \mathrm{m}^{3}$ on an annual average.

Figures 4 and 3 show the annual cycle of measured and observed nitrate mass. The tendency to underestimate North American nitrate mass, as seen in Fig. 2 seems to be caused in the winter. The model shows at several European stations too high nitrate concentrations in the winter month, caused by corse mode nitrate. Possibly, too much Saharan dust is transported in the model to Europe in that season.

Figure 5 presents aircraft campaign data, compared to the model average for the month the campaign took place. Overall the model follows nicely the vertical distribution of nitrate in the atmosphere. Including heterogeneous dust chemistry improves the performance of the model, although it leads occasionally to overprediction of nitrate between $3-8 \mathrm{~km}$ height. It is interesting to note how strongly nitrate aerosols are effected by these heterogeneous reactions, especially in 
Table 2. Annual mean aerosol and trace gas burden.

\begin{tabular}{|c|c|c|c|c|c|c|c|c|c|c|}
\hline & & $\begin{array}{l}\mathrm{SO}_{2} \\
{\left[\mathrm{Tg} \mathrm{S} \mathrm{yr}^{-1}\right]}\end{array}$ & $\mathrm{SO}_{4}$ & $\mathrm{SO}_{4(d u s t)}$ & $\begin{array}{l}\mathrm{NO}_{\mathrm{X}} \\
{\left[\mathrm{Tg} \mathrm{N} \mathrm{yr}^{-1}\right]}\end{array}$ & $\mathrm{HNO}_{3}$ & $\mathrm{NH}_{3}$ & $\mathrm{NH}_{4}$ & $\mathrm{NO}_{3}$ & $\mathrm{NO}_{3 \text { (dust) }}$ \\
\hline 1990 & & & & & & & & & & \\
\hline $\begin{array}{l}\text { Control } \\
2030\end{array}$ & CTR-00 & 0.48 & 0.34 & 0.22 & 0.53 & 3.88 & 0.17 & 0.27 & 0.11 & 0.41 \\
\hline Control & CTR-30 & 0.51 & 0.47 & 0.27 & 0.53 & 3.97 & 0.19 & 0.38 & 0.14 & 0.53 \\
\hline 2000 Climate & E30-00 & 0.49 & 0.48 & 0.28 & 0.54 & 3.99 & 0.18 & 0.41 & 0.15 & 0.56 \\
\hline $2000 \mathrm{NH}_{3}$ & NH3-30 & 0.51 & 0.47 & 0.27 & 0.53 & 3.98 & 0.13 & 0.35 & 0.10 & 0.56 \\
\hline $2000 \mathrm{SO}_{2}$ & SO2-30 & 0.48 & 0.34 & 0.20 & 0.53 & 3.95 & 0.22 & 0.32 & 0.15 & 0.53 \\
\hline $2000 \mathrm{NO}_{\mathrm{X}}$ & $\mathrm{NO}_{\mathrm{X}}-30$ & 0.53 & 0.42 & 0.30 & 0.52 & 3.86 & 0.21 & 0.36 & 0.13 & 0.52 \\
\hline Dust Surface Reac. & HET-30 & 0.72 & 0.68 & - & 0.53 & 4.41 & 0.13 & 0.47 & 0.11 & - \\
\hline
\end{tabular}

the regions of the PEM tropics campaign (South Pacific) and ACE ASIA (East Asia).

\section{Current and future atmospheric composition}

Future nitrate aerosol concentrations are influenced by climate and emission changes. The climate change due to $\mathrm{CO}_{2}$ increases as simulated in the GISS model between the years 2000 and 2030 is described in detail by Unger et al. (2006), which used with the same model version as employed in this study. In summary, the 2030 atmosphere is warmer and more humid, with an increase of $0.78^{\circ} \mathrm{C}$ in global annual mean surface air temperature. A large surface air temperature warming exceeding $2^{\circ} \mathrm{C}$ occurs over the South and North Polar regions, central North America and central Asia.

\subsection{Atmospheric composition}

As discussed in Sect. 2 sulfuric acid competes with nitrate for ammonia. Therefore we discuss the change in future sulphate first before referring to nitrate. Figure 6 shows maps of the difference between 2000 and 2030 in near surface concentrations. The changes in near surface $\mathrm{SO}_{2}$ concentrations follow closely the changes in $\mathrm{SO}_{2}$ emissions (see Fig. 1), and carry forward into the changes seen in the near surface ammonium and sulphate distributions. Sulphate concentrations decrease in Europe and the United States and increase elsewhere. The changes between 2000 and 2030 in column burden of fine mode sulphate and sulphate that has formed on dust surfaces (see Fig. 8) shows a similar pattern as presented for the near surface concentrations. The global mean fine mode sulphate burden increases from 0.34 to 0.47 [Tg $\mathrm{S} \mathrm{yr}^{-1}$ ], between 2000 and 2030 and sulphate on dust from 0.22 to 0.27 [ $\mathrm{Tg} \mathrm{S} \mathrm{yr}^{-1}$ ] (see Table 2). This will lead to an overall increase of $24 \%$ in total sulphate mass present in the atmosphere.

The changes in near surface concentrations (Fig. 6) of ambient $\mathrm{NO}_{\mathrm{x}}$ and nitric acid, reflect the changes in $\mathrm{NO}_{\mathrm{x}}$ emis- sions (Fig. 1). The changes in ambient near surface ammonia concentrations are more complex. Increased $\mathrm{NH}_{3}$ in China and India, and smaller increases in Europe, USA and Australia, colocate with the changes in its emissions. However $\mathrm{NH}_{3}$ decreases, occurring in Arabia, Central and East Africa and South America, collocate with increased $\mathrm{SO}_{2}$ emissions, which in turn leads to enhanced sulphate formation, whereby more ammonia is removed from the ambient air. The changes in the near surface nitrate aerosol concentrations generally reflect the discussed changes in ambient ammonia and $\mathrm{NO}_{\mathrm{y}}$ concentrations. This causes a large increase in near surface nitrate aerosols in China of $3 \mu \mathrm{g} \mathrm{m}^{-3}$, a moderate increase of $1 \mu \mathrm{g} \mathrm{m}^{-3}$ in Europe and India, and a slight decrease in Central U.S. The atmospheric load of fine mode nitrate aerosols has similar horizontal distributions in 2000 and 2030, although the concentrations in the already most polluted regions increase even more. The most dramatic increase in the column burden of nitrate aerosols is projected to take place in East China. The global mean load of fine mode nitrate increases from 0.11 to 0.14 [ $\left.\mathrm{Tg} \mathrm{N} \mathrm{yr}^{-1}\right]$, and the mass of nitrate that is attached on mineral dust from 0.41 to $0.53[\mathrm{Tg}$ $\mathrm{N} \mathrm{yr}^{-1}$ ]. Overall this would be an increase of $22 \%$ of nitrate material in our atmosphere within a time period of 30 years.

\section{Sensitivity studies}

A series of sensitivity studies are carried out, as described in Sect. 3. The results are summarized in Fig. 9 where the percentage changes in tropospheric burdens of $\mathrm{SO}_{2}, \mathrm{HNO}_{3}$, $\mathrm{NO}_{\mathrm{x}}$, PAN (peroxyacytyl nitrate), tropospheric ozone, $\mathrm{NH}_{3}$ and $\mathrm{NH}_{4}$, pure sulphate, pure nitrate, dust, sulphate on dust (named SO4 D), nitrate on dust (NO3 D), total nitrate (NO3 $\mathrm{T}$ ) and total sulphate ( $\mathrm{SO} 4 \mathrm{~T}$ ), are displayed compared to the base experiment CTR-30.

Present day simulation (CTR-00): Here we compare the two base-line experiments for the years 2000 and 2030. These are the same two experiments as already described in detail in Sect. 5. Generally, all trace gas and aerosol burdens 

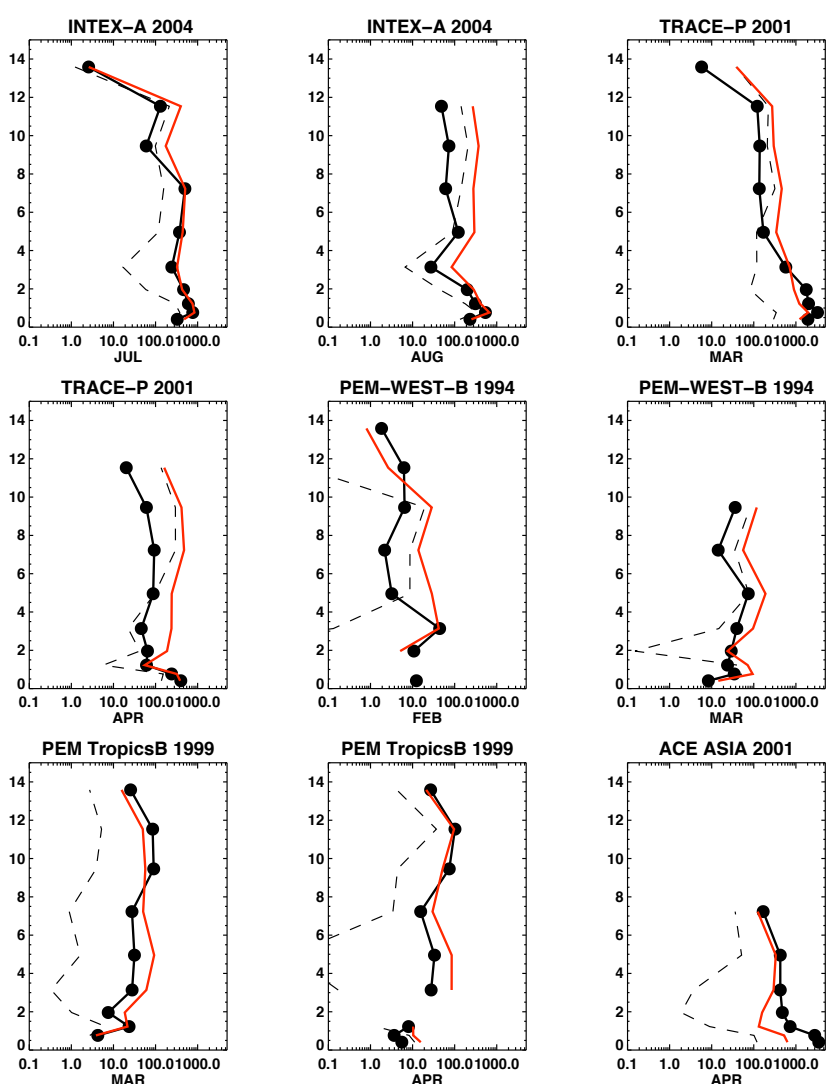

Fig. 5. Vertical profiles of nitrate concentrations in $\left[\mathrm{ppt}_{v}\right]$ as observed during various field campaigns by the DC8 air plane (black line), compared to the models total (fine and coarse mode) nitrate (red line) and its fine mode fraction (black dotted line) only. The title shows the name and the year or the campaign, and the subtitle the month. INTEX-A covers Eastern US (Singh et al., 2006), TRACE-P the North Hemispheric Western Pacific (Jacob et al., 2003), PEMWEST-B the Western Pacific (Hoell et al., 1997), PEM-Tropics the Southern Pacific (Raper et al., 2001) and ACE-ASIA East Asia and the Northern Pacific (Huebert et al., 2003). The model date are interpolated to the flight tracks and then the monthly mean vertical profiles are calculated.

show smaller amounts under present day condition compared to the future. However, the percentage change in airborne $\mathrm{NO}_{\mathrm{x}}$ and ozone are rather small and near surface ozone concentrations are reduced by $10 \%$. The only tracer with larger amount is mineral dust. This is because our simulated dust solubility depends on pollution coating on its surface. In a less polluted atmosphere, solubility will be smaller and therefore the overall dust burden larger. Changes in ammonium, sulphate and nitrate are substantial, between $20-30 \%$.

Future emissions, present day climate (CLIM): In this experiment the model was run under physical climate conditions of the year 2000 but using the anthropogenic gas and aerosol emissions for the year 2030. In comparison to all
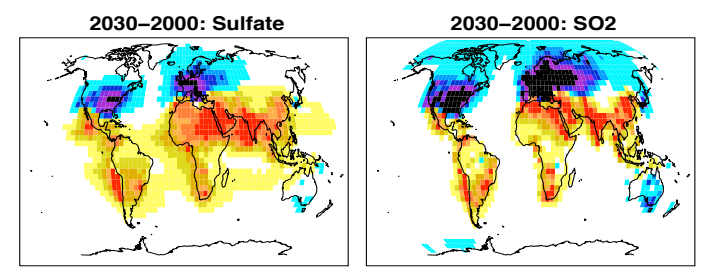

2030-2000: NOx

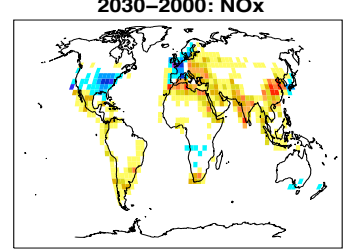

2030-2000: HNO3

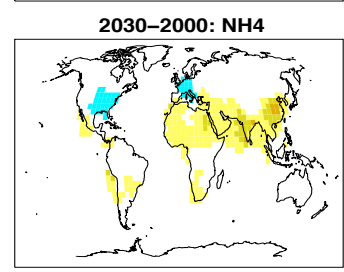

2030-2000: Nitrate
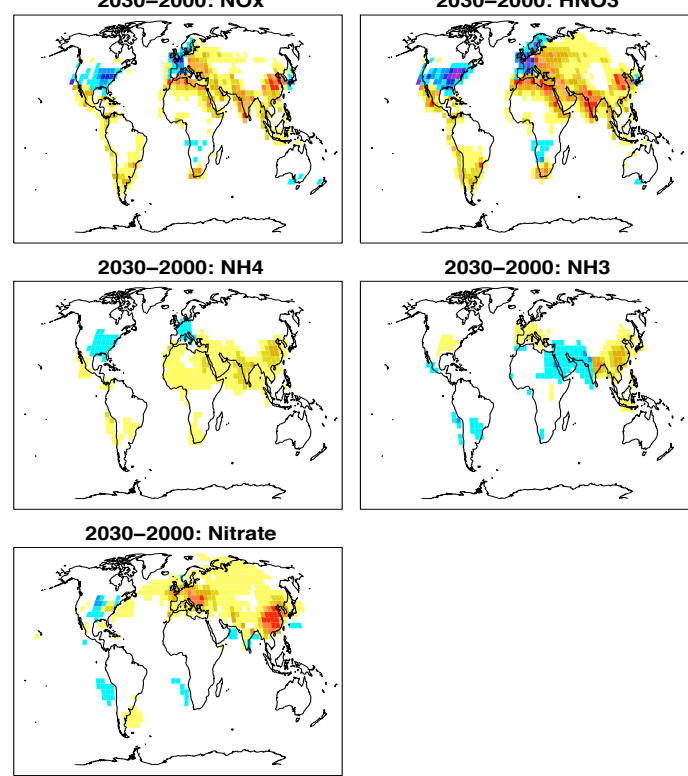

2030-2000: NH3

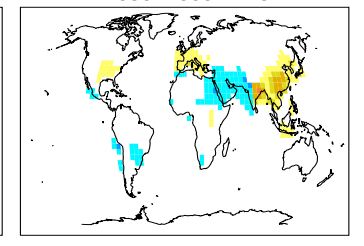

2

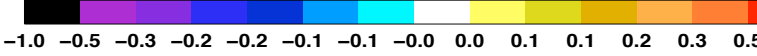

Fig. 6. Difference between the years 2030 and 2000 in near surface concentrations, in $\left[\mu \mathrm{g} / \mathrm{m}^{3}\right]$, of $\mathrm{SO}_{2}, \mathrm{NO}_{\mathrm{x}}, \mathrm{HNO}_{3}, \mathrm{NH}_{4}, \mathrm{NH}_{3}$ and fine mode nitrate.

the other sensitivity experiments, this case shows the lowest impact on the atmospheric composition. The global mean nitrate aerosol burden is increased by $6 \%$ compared to the CTR-2030 experiment. This is caused by a slight increase in ammonium oxidation, due to enhanced $\mathrm{OH}$ as humidity is increased. However, the overall signal is small and the largest percentage change is seen in nitrate aerosol concentrations, which especially increase in Europe, North America and China.

Future simulation with $2000 \mathrm{SO}_{2}$ emissions (SO2): In this experiment the future climate, 2030, was simulated as in the CTR-30 experiment, but the $\mathrm{SO}_{2}$ emissions of the year 2000 are used, instead of its future projection. This experiment has a large impact on sulphate formation. Sulphates get reduced by roughly $30 \%$, which leads to an overall increase in nitrate aerosol of about $8 \%$, because relatively smaller sulphate concentrations leads to favorable reaction of ammonia with nitric acid to form ammonium nitrate instead of reaction with sulphate. 


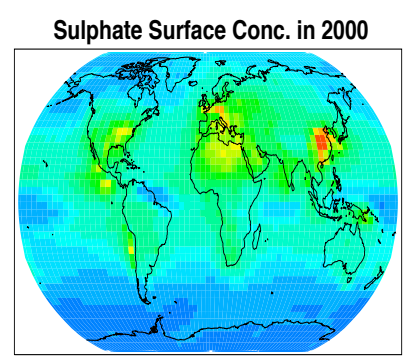

Sulphate Surface Conc. in 2030

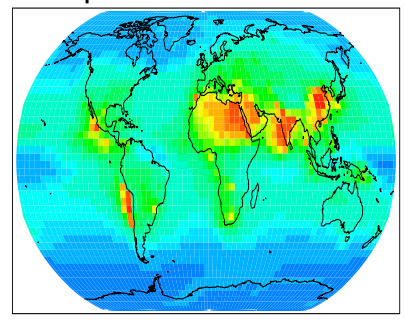

Nitrate Surface Conc. in 2000

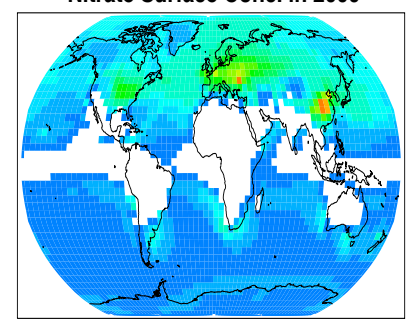

Nitrate Surface Conc. in 2030

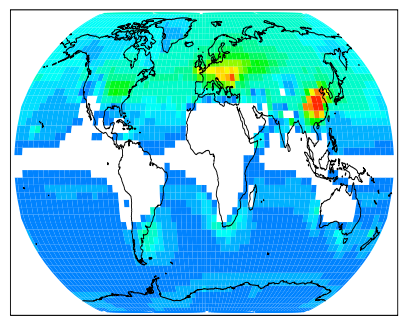

$\begin{array}{llllllllll}0.00 & 0.02 & 0.04 & 0.10 & 0.30 & 0.50 & 0.70 & 0.90 & 1.20 & 2.00\end{array}$

Fig. 7. Annual mean near surface concentrations of fine mode sulphate (upper panel) aerosols and nitrate (lower panel) for the year 2000, and 2030. Units are in $\left[\mu \mathrm{g} / \mathrm{m}^{3}\right]$.

Future simulation with $2000 N O_{\mathrm{x}}$ emissions $\left(N O_{\mathrm{x}}\right)$ : Here the future was simulated but with the $\mathrm{NO}_{\mathrm{x}}$ emissions fixed to present day emission levels. The year $2000 \mathrm{NO}_{\mathrm{x}}$ emissions are $33 \%$ smaller than the predicted $\mathrm{NO}_{\mathrm{x}}$ emissions of the year 2030. Employing the lower $\mathrm{NO}_{\mathrm{x}}$ emissions in this sensitivity test leads consequently to smaller ambient $\mathrm{NO}_{\mathrm{x}}$ $(-2 \%), \mathrm{HNO}_{3}(-3 \%), \mathrm{N}_{2} \mathrm{O}_{5}(-8 \%)$ and PAN (-9\%) concentrations. Near surface ozone concentration is decreased by $-5 \%$, but the overall ozone burden is just slightly reduced, as most of the ozone mass is located in the upper troposphere. The overall impact on fine mode nitrate aerosol is a decrease of about $7 \%$ of its burden, and the nitrate material that is mixed with mineral dust particles is reduced by $23 \%$. Most likely the reduced amount of nitrogen containing gases, especially the reduced ambient concentrations of nitric acid over the Sahara and the Arabian and Chinese deserts (which reflects the $\mathrm{NO}_{\mathrm{x}}$ emission changes as displayed in Fig. 1), leads to this strong effect on the development of nitrate coatings on mineral dust particles. However, the formation of sulphate coatings is enhanced in this simulation, which might be caused by more free reactive mineral dust surfaces, due to the reduced amount of nitrate coatings. More sulphate coating, in turn leads to more oxidation of $\mathrm{SO}_{2}$ and reduced concentrations of externally mixed ammonium-sulphate.

Future simulation with $2000 \mathrm{NH}_{3}$ emissions (NH3): This time the future was simulated but neglecting the expected changes in ammonia emissions. Ammonia emissions have hardly any impact on the sulphate and the ozone cycle, but impact significantly nitrate production. Less $\mathrm{NH}_{3}$ emissions leads logically to less ambient $\mathrm{NH}_{3}, \mathrm{NH}_{4}$ and consequently to less ammonium-nitrate aerosol, which is reduced by $30 \%$ relative to the CTR-30.

Excluding heterogeneous reactions on mineral dust surfaces (HET): All simulations, baseline experiments and the other sensitivity experiments, include the heterogeneous formation of nitrate and sulphate coatings on mineral dust surfaces. This reaction pathway impacts the formation of ammonium-sulfate and ammonium-nitrate aerosols, as well as the solubility of mineral dust (Bauer et al., 2007; Bauer and Koch, 2005; Bauer et al., 2004). In the sensitivity experiment HET no such heterogeneous reactions took place. The experiment emissions and physical climate are identical to the baseline experiment CTR-30. Neglecting the oxidation of $\mathrm{SO}_{2}$ on dust, leads to larger ambient $\mathrm{SO}_{2}(40 \%)$, ammonium-sulphate (45\%) and mineral dust (25\%) burden. Nitric acid is an important precursor gas for nitrate formation but also reacts with the mineral dust surfaces. Globally it is increased by $10 \%$ between CTR-30 and HET, but locally in the Northern African and Arabic regions the increase is much larger (up to $60 \%$ over India). Therefore the induced amounts of nitric acid in HET simulation would lead to increased ammonium nitrate aerosol formation. However, externally mixed ammonium nitrate mass is reduced in HET, especially in the Northern Hemisphere background atmosphere. This is caused by increased externally mixed sulphate concentrations in HET. Sulphate can be neutralized by ammonia, the residual amount of ammonia might neutralize nitric acid to form ammonium nitrate. In HET the higher sulphate concentration leads to less free ammonia $(-30 \%)$ and therefore a reduced nitrate production. This phenomenon was already discussed in Bauer et al. (2007) for current climate conditions. Due to the increase of $\mathrm{SO}_{2}$ and $\mathrm{NO}_{x}$ sources (see Fig. 1) at the coasts of Africa, China and the Arabian region, in direct vicinity of desert regions, this effect is much more pronounced in the more polluted, future atmosphere.

\section{Radiative forcings}

The global mean top of the atmosphere instantaneous radiative forcing (hereafter RF) is shown in Fig. 10 for ozone and for sulphate, nitrate, black and organic carbon and dust as a result of their individual contribution as external mixtures. The impact of sulphate and nitrate coatings on the optical properties of the coated dust particles is negligible as usually the shell thickness of the coating nitrate or sulphate material is too thin to significantly change the optical properties of the core dust particle (Bauer et al., 2007). RF are calculated as the sum of the individual short wave and long wave contributions, however only ozone and mineral dust have significant forcing in the long-wave spectrum. Figure 10 shows maps of the forcings for the year 2000 and the changes between 2030 and 2000. 

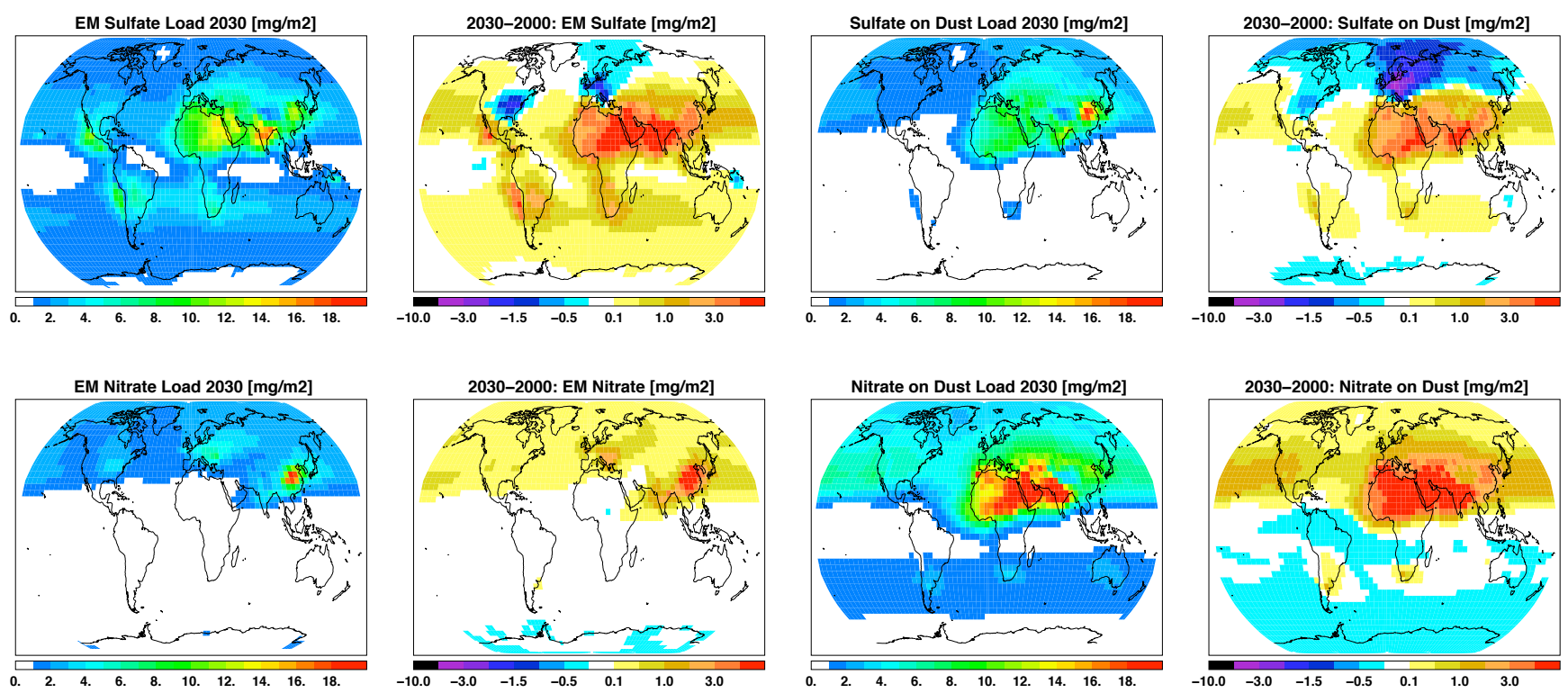

Fig. 8. Annual mean total column load for sulphate and nitrate aerosols of the year 2000, and the differences between 2030-2000. The first two maps show the externally mixed (EM), fine mode, sulphate contribution and the following two maps the coarse mode sulphate mass that is mixed with mineral dust. The second row shows the same maps but for nitrate aerosol. Units are $\left[\mathrm{mg} / \mathrm{m}^{2}\right]$.

Table 3. Radiative forcings in different eras $\left[\mathrm{W} / \mathrm{m}^{2}\right]$.

\begin{tabular}{llll|ll}
\hline & 1750 & 2000 & 2030 & $\Delta 2000-1750$ & $\Delta 2030-2000$ \\
\hline Sulphate & -0.26 & -0.45 & -0.62 & -0.19 & -0.17 \\
Nitrate & -0.05 & -0.11 & -0.14 & -0.06 & -0.03 \\
Black carbon & +0.04 & +0.33 & +0.28 & +0.29 & -0.05 \\
Organic carbon & -0.04 & -0.17 & -0.14 & -0.13 & +0.03 \\
Ozone & -0.67 & -0.40 & -0.27 & +0.27 & +0.13 \\
Dust & -0.60 & -0.57 & -0.52 & +0.03 & +0.05 \\
All & -1.62 & -1.37 & -1.41 & +0.25 & -0.04 \\
\hline
\end{tabular}

Nitrate aerosols, like sulphate, have a single scattering albedo close to unity and therefore mainly scatter solar radiation, which leads to a cooling of the atmosphere. Nitrate aerosols lead to forcing signals in areas of high nitrate burden. This forcing is enhanced for large $\mathrm{RH}$ as the particles take up water. Figure 10 shows that nitrate has a stronger negative forcing signal in the Northern Hemisphere, with local maximum values over China and Europe of up to $-1 \mathrm{~W} / \mathrm{m}^{2}$. Further increase of the negative forcing is predicted to happen in the next 30 years. All changes appear in the Northern Hemisphere, with again largest contributions over Europe and Asia. Locally the radiative forcing due to nitrate aerosols will be of the order of $-4 \mathrm{~W} / \mathrm{m}^{2}$ over China. Sulphate aerosol predicted changes for the next 30 years show an increase in the tropical regions, especially over India (locally up to $-3 \mathrm{~W} / \mathrm{m}^{2}$ ). Due to $\mathrm{SO}_{2}$ emission reductions in the United States and Europe, sulphate forcing decreases in these regions. The future emission scenario we employed in this simulation predicts strong reductions in carbonaceous aerosols (Koch et al., 2007b), which leads to a reduction in absorbing black and scattering organic carbon. The positive radiative forcing of black carbon gets reduced mostly all over the Northern Hemisphere and the African biomass burning region. The reduction in organic carbon leads to a reduced negative forcing. The forcing signal of ozone is more homogeneous because of its longer lifetime, and the increase of the global ozone concentration leads to a positive forcing. Ozone RF increases by $0.03 \mathrm{~W} / \mathrm{m}^{2}$ in the short wave length and $0.1 \mathrm{~W} / \mathrm{m}^{2}$ in the long wave length. The changes we see in the mineral dust RF signal is mainly caused by solubility changes of the dust particles. In these simulations pure dust is assumed to be insoluble and nitrate or sulphate 


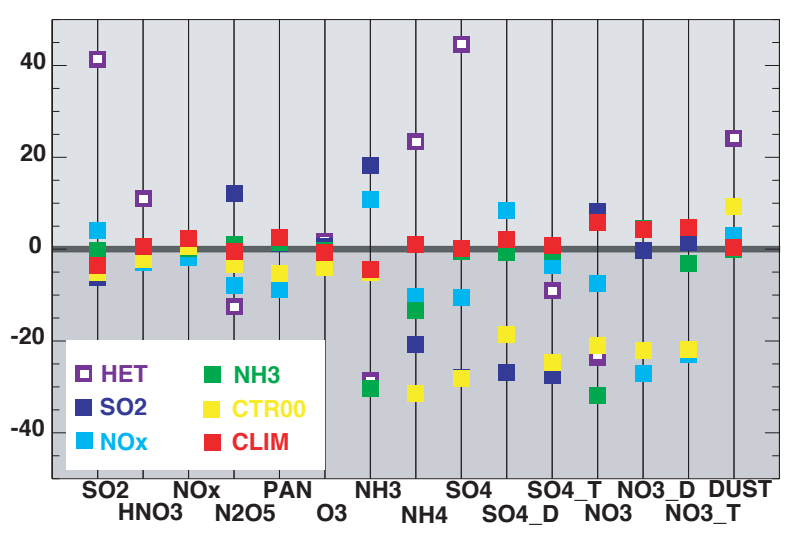

Fig. 9. Percentage change in gas and aerosol burdens of the CTR00, E30-00 (CLIM), SO2-00, NOx-00, NH3-00 and HET-30 experiment, compared to CTR-30. The global annual mean percentage changes are presented for gaseous: $\mathrm{SO}_{2}, \mathrm{HNO}_{3}, \mathrm{NO}_{\mathrm{x}}, \mathrm{PAN}$ (peroxyacytyl nitrate), tropospheric ozone, $\mathrm{NH}_{3}$ and $\mathrm{NH}_{4}$; and aerosols: fine mode sulphate, coarse mode sulphate (SO4 D), total sulphate (SO4 T), fine mode nitrate (NO3), coarse mode nitrate (NO3 D), total nitrate (NO3 $\mathrm{T}$ ) and mineral dust.

coatings influence its solubility, which leads to more wet deposition of dust in a more nitrate- and sulphate-polluted future atmosphere. Mineral dust scatters and absorbs solar radiation. Scattering dominates in the short wave spectra and therefore mineral dust changes have a negative short-wave $\mathrm{RF}$ of $-0.08 \mathrm{~W} / \mathrm{m}^{2}$, which is partly counterbalanced by its long wave contribution of 0.04 for RF.

The last map in Fig. 10 shows the net aerosol and ozone forcing. The overall change in RF has a negative sign, with strongest negative RFs over India and China. In these regions, the predicted sulphate and nitrate increases and black carbon decreases, all contribute to this large negative forcing. Overall negative RF changes dominate over land whereas the RF change is positive over oceans (mostly caused by the contribution of ozone RF), except the North Pacific where the Asian pollution plume contributes to a negative forcing. In the Arctic the forcing between present-day and pre-industrial (PI) is positive (Koch et al., 2007b), however it is projected to decline in the future (Koch et al., 2007a).

The magnitude of the global mean aerosol and ozone top of the atmosphere RFs are given in Table 3 for pre-industrial conditions (e.g. 1750), present day (year 2000) and the near future (2030). The pre-industrial numbers are derived from a run where all anthropogenic emissions where excluded. The run is discussed in detail in Bauer et al. (2007).

Before industrialization began, ozone and aerosols mostly contribute to cooling of this planet, and the largest contribution came from the ozone molecules. According to our simulation, under present day conditions sulphate particles play the leading role in cooling the atmosphere and this role will be even more pronounced in the near future. Nitrate aerosol plays a smaller role, but it's contribution has nearly tripled since pre-industrial times. In the near future nitrate will have a RF that is comparable to the RF of organic carbon.

\section{Conclusions}

The GISS climate model is used to study the role of nitrate aerosols in the changing atmosphere. Future emission projection along the SRES A1B scenario were used to simulate the year 2030. This paper concentrates on the year 2030, the near future, because emission prediction are highly uncertain and uncertainty increases with projection length.

The evaluation of the present day nitrate concentration is difficult, because of the limited number of observational data and the coarse nature of our model. Surface observations are available from the IMPROVE, EMEP and Prospero networks, and vertical profiles from various aircraft campaigns from around the world. The overall agreement between model and data sets is good, but the model tends to underestimates nitrate mass by an order of magnitude in East Asia. We conclude that the ammonia emission (Bouwman et al., 1997) and the EDGAR inventory needs updating in that region. The comparison at remote stations showed the importance of the formation of nitrate on mineral dust particles, because when only comparing the simulated fine mode fraction the measurements highly underestimate at the remote sites. Unfortunately, the measurement are bulk mass observations and don't contain information on which mixing state the nitrate was observed.

Fine mode aerosol particles are dangerous air pollutants that have the ability to travel deep into the lungs and lead to serious health problems. The near surface concentrations of fine mode sulphate and nitrate particles show in our present day simulation maximum concentrations of about $1.5 \mu \mathrm{g} / \mathrm{m}^{3}$ in the most polluted areas like East China and Europe. In the year 2030 simulation, the fine sulphate and nitrate concentration climb as high as $4 \mu \mathrm{g} / \mathrm{m}^{3}$ in sulphate and $3 \mu \mathrm{g} / \mathrm{m}^{3}$ in nitrate concentrations. As nitrate pollution was already strongly underestimated in the present day simulation, we assume that the future numbers are underestimated as well. Note that these numbers reflect annual mean concentrations, and actual seasonal and daily maximum concentrations will reach much higher concentration levels.

Future nitrate concentrations result from changes in the physical and chemical state of the future atmosphere. To be able to understand which of the expected changes are most important for nitrate formation, we performed a series of sensitivity studies where one of the future predicted changes were kept at its current day conditions. Through these experiments we learned that the physical climate change, e.g. temperature and humidity rise, have only a very small impact on future nitrate concentrations. Studying the impact of single emitted gas precursors showed that future nitrate depends most strongly on the emission strength of ammonia. 

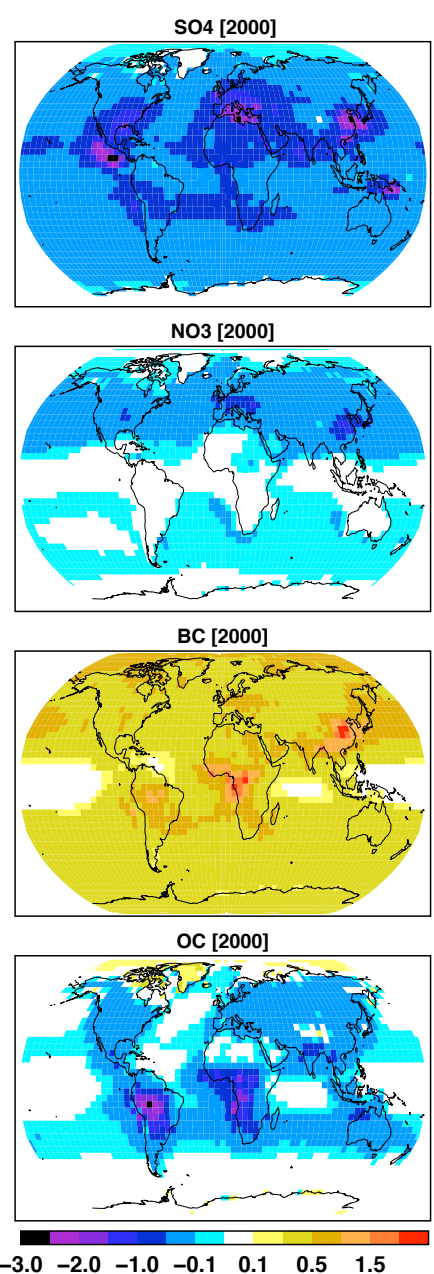
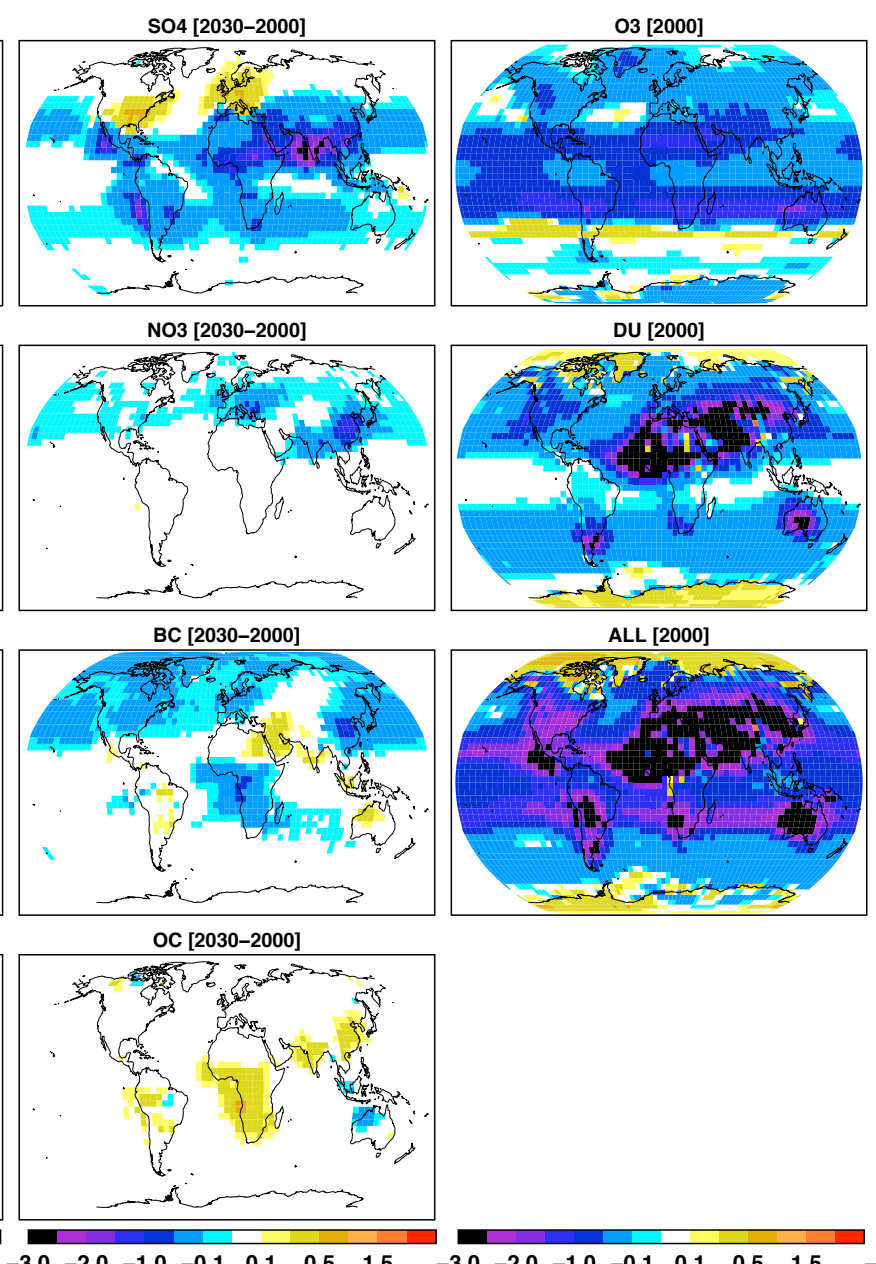
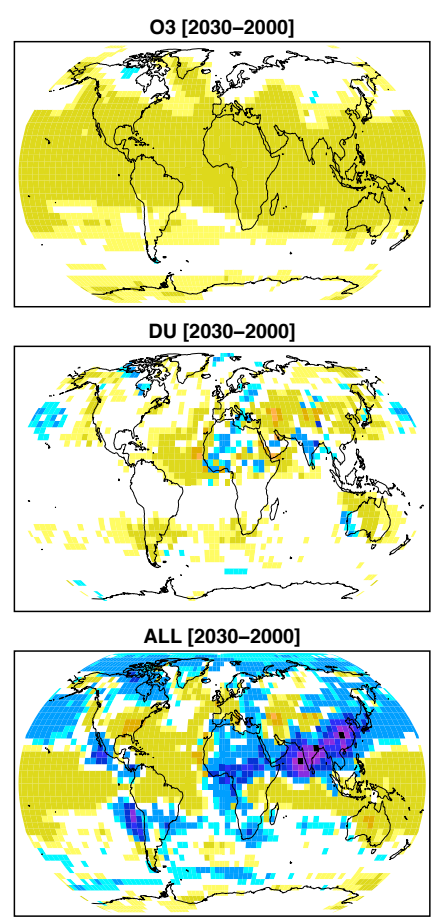

Fig. 10. Top of the atmosphere radiative forcings $\left[\mathrm{W} / \mathrm{m}^{2}\right]$ of each individual aerosol species (fine mode sulphate $\left(\mathrm{SO}_{4}\right)$ and nitrate $\left(\mathrm{NO}_{3}\right)$, black (BC) and organic (OC) carbon, mineral dust (DU) and ozone $\left(\mathrm{O}_{3}\right)$. The maps entitled "ALL" shows the sum of all aerosols and gases, the net forcing. The forcings are shown for the year 2000 and the differences between 2030 and 2000.

Other changes in emitted gases like $\mathrm{NO}_{\mathrm{x}}$ and $\mathrm{SO}_{2}$, only play a minor role. In one of the sensitivity experiments the heterogeneous reactions involving mineral dust particles are neglected. That experiment had a very strong impact on future nitrate concentration. And even beyond nitrate, this sensitivity experiment changed dramatically the concentrations of $\mathrm{SO}_{2}$, sulphate, $\mathrm{N}_{2} \mathrm{O}_{5}, \mathrm{NH}_{4}, \mathrm{NH}_{3}$ and dust. In our simulation most of the aerosols are treated as external mixtures, only nitrate and sulphates can mix with mineral dust, therefore this is only one step towards the representation of truly mixed and coated aerosol particles. Nevertheless it is interesting to see how important the consideration of mixtures might be, especially for species like sulphates and nitrates that mainly form in the atmosphere out of precursor gases. These precursors are very likely to condense on existing particles in the atmosphere and therefore are likely to exist as aerosol mixtures or coatings, especially if the particles have been airborne and aged for some time and were released or produced in areas where a mix of particles is already present in the air. For example in China, where urban pollution frequently mixes with dust particles.

Future emission inventories predict a large increase of pollution precursors around the Northern coasts of Africa and throughout Arabia. This pollution is very likely to mix with desert dust, as it's sources are very close to the desert regions, therefore mixing between aerosol species might be getting even more pronounced in the future atmosphere.

In summary, we conclude from our sensitivity studies, that for understanding future ammonium-nitrate concentrations it is important to have good estimates of ammonia emissions and to have measurement data regarding the mixing state of aerosols.

In addition to the role aerosols play as dangerous air pollutants, they also interact with the climate system by interacting 
with the Earths radiation budget and cloud microphysics. The latter point is not studied in this paper and possibly might have a greater impact on the Earth climate than direct radiative forcing. However, in our study we find for present day conditions a direct nitrate radiative forcing of $-0.11 \mathrm{~W} \mathrm{~m}^{-2}$ which lies in between the forcings calculated in other studies: -0.19 Adams et al. (2001), -0.16 Liao and Seinfeld (2005); Liao et al. (2006), -0.04 Jacobson (2001), -0.02 Myhre et al. (2006). Note that the studies estimating the smaller nitrate radiative forcings considered aerosol mixing. Myhre et al. (2006) who only considered nitrate and sea salt mixing found that the inclusion on sea salt and nitrate particle mixtures reduced the aerosol optical thickness by $25 \%$. Jacobson (2001) placed $90 \%$ of his nitrate in the coarse mode, based on observational data. In a recent and more detailed study of aerosol thermodynamics Martin et al. (2004) found that burden and radiative forcing of nitrate was about $10-15 \%$ those of sulphate. Martin et al. (2004) also take into account formation of solids. They find that the combined radiative forcing of the nitrate/ammonia/sulphate aerosol changed by approximately $25 \%$ depending on whether the upper side or the lower side of the hysteresis loop controlling water uptake of the aerosol was used. None of these studies predicted aerosol concentrations for the year 2030, but Liao and Admas calculated the RF for the year 2100 under the SRES A2 scenario, of -0.95 and $-1.28 \mathrm{~W} / \mathrm{m}^{2}$.

Compared to other aerosol forcings, in this paper nitrate $\mathrm{RF}$ has the same order of magnitude as organic carbon, and roughly a quarter of the magnitude of that of sulphate aerosols. These relations seem to be conserved in our simulations during present day, pre-industrial and A1B 2030 conditions. Analyzing the changes between the different eras, pre-industrial and present-day and 2030, we find that the total change in aerosol and tropospheric ozone forcing changes from $0.25 \mathrm{~W} \mathrm{~m}^{-2}(1750-2000)$ to a negative forcing of $-0.04 \mathrm{~W} \mathrm{~m}^{-2}$. These changes are mainly caused by the large reduction in carbonaceous emissions in the near future. In relation to the dramatic changes in black and organic carbon, nitrate RF increase is rather small. It is expected to increase by $0.03 \mathrm{~W} \mathrm{~m}^{-2}$ in the next 30 years, compared to an increase of $0.06 \mathrm{~W} \mathrm{~m}^{-2}$ in the last 250 years.

The role of aerosols in climate change is very complex, due to the absorbing and scattering nature of different aerosols which leads to negative and positive contributions that partly cancel out each other. Future emission scenarios that take into account emission reductions, for example like the reduced carbonaceous emission in the SRES A1B, will lead to an even smaller contribution of aerosol forcing in the future. In contrast we have the steadily increasing long lived greenhouse gas (LLGHG) emissions, like carbon dioxide, methane, nitrogen oxide and CFCs, that are most likely steadily increasing. At present day the LLGHG contribute $2.6 \mathrm{~W} \mathrm{~m}^{-2}$ to the warming of our planet and are expected to rise up to $3.9 \mathrm{~W} \mathrm{~m}^{-2}$ by the year 2030 (?). The combined aerosol (excluding sea salt aerosols) and ozone RF is
$-1.37 \mathrm{~W} \mathrm{~m}^{-2}$ under current climate and $-1.41 \mathrm{~W} / \mathrm{m}^{2}$ for the year 2030 .

Acknowledgements. This work has been supported by the NASA MAP program Modeling, Analysis and Prediction Climate Variability and Change (NN-H-04-Z-YS-008-N), managed by D. Anderson. We acknowledge the IMPROVE and EMEP network, and the NASA GTE campaign data sets. The author like to thank J. Crawford, for advice on the GTE data set (http://www-gte.larc.nasa.gov/).

Edited by: U. Lohmann

\section{References}

Adams, P. J., Seinfeld, J. H., Koch, D., Mickley, L., and Jacob, D.: General circulation model assessment of direct radiative forcing by the sulfate-nitrate-ammonium-water inorganic aerosol system, J. Geophys. Res, 106, 1097-1112, doi:10.1029/2000JD900 512, 2001.

Amundson, N. R., Caboussat, A., He, J. W., Martynenko, A. V., Savarin, V. B., Seinfeld, J. H., and Yoo, K.-Y.: A new inorganic atmospheric aerosol phase equilibrium model (UHAERO), Atmos. Chem. Phys., 6, 975-992, 2006,

http://www.atmos-chem-phys.net/6/975/2006/.

Ansari, A. S. and Pandis, S. N.: Prediction of multicomponent inorganic atmospheric aerosol behavior, Atmos. Environ., 33(5), 745-757, 1999.

Bassett, M. and Seinfeld, J. H.: Atmospheric equilibrium model of sulfate and nitrate aerosol, Atmos. Environ., 17, 2237-2252, 1983.

Bassett, M. and Seinfeld, J. H.: Atmospheric equilibrium model of sulfate and nitrate aerosols-II. particle size analysis, Atmos. Environ., 18, 1163-1170, 1984.

Bauer, S. E. and Koch, D.: Impact of Heterogeneous Sulfate Formation at Mineral Dust Surfaces on Aerosol Loads and Radiative Forcing in the GISS GCM, J. Geophys. Rev., 112, D17202, doi:10.1029/2005JD005870, 2005.

Bauer, S. E., Balkanski, Y., Schulz, M., Hauglustaine, D. A., and Dentener, F.: Global modelling of heterogeneous chemistry on mineral aerosol surfaces: The influence on tropospheric ozone chemistry and comparison to observations, J. Geophys. Res., 109, D02304, doi:10.1029/2003JD003868, 2004.

Bauer, S. E., Mishchenko, M., Lacis, A., Zhang, S., Perlwitz, J., and Metzger, S.: Do Sulfate and Nitrate Coatings on Mineral Dust have Important Effects on Radiative Properties and Climate Modeling?, J. Geophys. Rev., 112, D06307, doi:10.1029/2005JD006977, 2007.

Binkowski, F. and Shankar, U.: The regional particulate matter model, 1: model description and preliminary results, J. Geophys. Res., 100(D12), 26 191-26210, doi:10.1029/95JD02093, 1995.

Bond, T. C., Streets, D., Yarber, K., Nelson, S., Woo, J., and Klimont, Z.: A technology-based global inventory of black and organic carbon emissions form combustion, J. Geophys. Res, 109, D14203, doi:10.1029/2003JD003697, 2004.

Bouwman, A. F., Lee, D. S., Asman, W. A. H., Dentener, F. J., Hoek, K. W. V. D., and Olivier, J.: A Global High-Resolution Emission Inventory for Ammonia, Global Biogeochem. Cycles, 11, 561-587, 1997. 
Clegg, S. and Pitzer, K. S.: Thermodynamics of multicomponent, miscible, ionic solutions: generalized equations for symmetrical electrolytes, J. Phys. Chem, 96(8), 3513-3520.431, 1992.

Clegg, S., Brimblecombe, P., and Wexler, A. S.: Thermodynamic model of the system $\mathrm{H}^{+}-\mathrm{NH}_{4}^{+}-\mathrm{Na}^{+}-\mathrm{SO}_{4}^{2-}--\mathrm{NO}_{3}^{-}-\mathrm{Cl}^{-}-\mathrm{H}_{2} \mathrm{O}$ at $298.15 \mathrm{~K}, \mathrm{~J}$. Phys. Chem., 102, 2155.448-2171.449, 1998a.

Clegg, S. L., Pitzer, K. S., and Brimblecombe, P.: Thermodynamics of multicomponent, miscible, ionic solutions. mixtures including unsymmetrical electrolytes, J. Phys. Chem, 96(23), 9470-9479, 1992.

Clegg, S. L., Brimblecombe, P., and Wexler, A. S.: Thermodynamic model of the system $\mathrm{H}^{+}-\mathrm{NH}_{4}^{+}-\mathrm{SO}_{4}^{2-}-\mathrm{NO}_{3}^{-}-\mathrm{H}_{2} \mathrm{O}$ at tropospheric temperatures, J. Phys. Chem., A, 102(12), 2137-2154, $1998 \mathrm{~b}$

Dentener, F. J., Carmichael, G. R., Zang, Y., Lelieveld, J., and Crutzen, P. J.: Role of mineral aerosol as a reactive surface in the global troposphere, J. Geophys. Res., 101, 22 869-22 889, 1996.

Feng, Y. and Penner, J. E.: Global modeling of nitrate and ammonium: Interaction of aerosols and tropospheric chemistry, J. Geophys. Res., 112, D01304, doi:10.1029/2005JD006404, 2007.

Goodman, A. L., Underwood, G. M., and Grassian, V. H.: A laboratory study of the heterogeneous reaction of nitric acid on calcium carbonate particles, J. Geophys. Res., 105, 29 053-29 064, 2000.

Guenther, A. B., Hewitt, N., Erickson, D., Fall, R., Geron, C., Graedel, T., Harley, P., Klinger, L., Lerdau, M., McKay, W. A., Pierce, T., Scholes, B., Steinbrecher, R., Tallamraju, R., Taylor, J., and Zimmerman., P.: A global model of natural volatile organic compound emissions, J. Geophys. Res., 100, 8873-8892, 1995.

Hansen, J., Sato, M., Ruedy, R., Nazarenko, L., Lacis, A., Schmidt, G., Russell, G., Aleinov, I., Bauer, M., Bauer, S., Bell, N., Cairns, B., Canuto, V., Cheng, Y., Genio, A. D., Faluvegi, G., Fleming, E., Friend, A., Hall, T., Jackman, C., Kelley, M., Kiang, N., Koch, D., Lean, J., Lerner, J., Lo, K., Menon, S., Miller, R., Minnis, P., Novakov, T., Oinas, V., Perlwitz, J., Perlwitz, J., Rind, D., Romanou, D., Shindell, D., Stone, P., Sun, S., Tausnev, N., Thresher, D., Wielicki, B., Wong, T., Yao, M., and Zhang, S.: Efficacy of Climate Forcing, J. Geophys. Res., 110, D18104, doi:10.1029/2005JD005776, 2005.

Hoell, J. M., Davis, D. D., Liu, S. C., Newell, R. E., Akimoto, H., McNeal, R. J., and Bendura, R. J.: The Pacific Exploratory Mission-West Phase B: February-March 1994., J. Geophys. Res., 102, 28 223-28 240, 1997.

Huebert, B., Bates, T., Russell, P., Shi, G., Kim, Y., Kawamura, K., Carmichael, G., and Nakajima, T.: An overview of ACEAsia: Strategies for quantifying the relationships between Asian aerosols and their climatic impacts, J. Geophys. Res, 108(D23), 8633, doi:10.1029/2003JD003550, 2003.

Jacob, D. J.: Heterogeneous chemistry and tropospheric ozone, Atmos. Environ., pp. 2131-2159, 2000.

Jacob, D. J., Crawford, J., Kleb, M., Connors, V. S., Bendura, R. J., Raper, J. L., Sachse, G. W., Gille, J. C., Emmons, L., and Held, C. L.: Transport and chemical evolution over the Pacific (TRACE-P) aircraft mission: Design execution and first results, J. Geophys. Res, 108(D20), 9000, doi:10.1029/2002JD003276, 2003.

Jacobson, M. Z.: Studying the effects of calcium and magnesium on size-distributed nitrate and ammonium with EQUISOLV II, Atmos. Environ., 33(22), 3635-3649, 1999.

Jacobson, M. Z.: Global direct radiative forcing due to multicomponent anthropogenic and natural aerosols, J. Geophys Res., 106, 1551-1568, 2001.

Jacobson, M. Z., Tabazadeh, A., and Turco, R. P.: Development and Application of a new air pollution modelling system - Part I. Gas-Phase Simulations, Atmos. Environ., 30B, 1939-1963, 1996.

Kim, Y. P. and Seinfeld, J. H.: Atmospheric gas-aerosol equilibrium III. thermodynamics of crustal elements $\mathrm{Ca}^{2+}-\mathrm{K}^{+}-\mathrm{Mg}^{2+}$, Aerosol Sci. Technol., 22(1), 93-110, 1995.

Kim, Y. P., Seinfeld, J. H., and Saxena, P.: Atmospheric gas-aerosol equilibrium I. thermodynamic model, Aerosol Sci. Technol., 19, 157-181, 1993a.

Kim, Y. P., Seinfeld, J. H., and Saxena, P.: Atmospheric gas-aerosol equilibrium II. analysis of common approximations and activity coefficient calculation methods, Aerosol Sci. Technol., 19, 182198, 1993b.

Kinne, S., Schulz, M., Textor, C., Guibert, S., Balkanski, Y., Bauer, S. E., Berntsen, T., Berglen, T., Boucher, O., Chin, M., Collins, W., Dentener, F., Diehl, T., Easter, R., Feichter, H., Fillmore, D., Ghan, S., Ginoux, P., Gong, S., Grini, A., Hendricks, J., Herzog, M., Horrowitz, L., Isaksen, I., Iversen, T., Kloster, A. K. S., Koch, D., Kristjansson, J. E., Krol, M., Lauer, A., Lamarque, J., Lesins, G., Liu, X., Lohmann, U., Montanaro, V., Myhre, G., Penner, J., Pitari, G., Reddy, S., Seland, O., Stier, P., Takemura, T., and Tie, X.: An AeroCom initial assessment - optical properties in aerosol component modules of global models, Atmos. Chem. Phys., 6, 1815-1834, 2006,

http://www.atmos-chem-phys.net/6/1815/2006/.

Koch, D. and Hansen, J.: Distant origins of Arctic soot: A GISS ModelE experiment, J. Geophys. Res, 110, D04204, doi:10.1029/2004JD005296, 2005.

Koch, D., Jacob, D., Tegen, I., Rind, D., and Chin, M.: Tropospheric sulfur simulation and sulfate direct radiative forcing in the Goddard Institute for Space Studies general circulation model, J. Geophys. Res., 104, 23 799-23 822, 1999.

Koch, D., Schmidt, G., and Field, C.: Sulfur, sea salt and radionuclide aerosols in the GISS modelE, J. Geophys. Res., 111, D06206, doi:10.1029/2004JD005550, 2006.

Koch, D., Bond, T., Streets, D., and Unger, N.: Linking future aerosol radiative forcing to shifts in source activities., Geophys. Res. Lett., 34, L05821, doi:10.1029/2006GL028360, 2007a.

Koch, D., Bond, T., Streets, D., Unger, N., and van der Werf, G.: Global impacts of aerosols from particular source regions and sectors, J. Geophys. Res, 112, D02205, doi:10.1029/2005JD007024, 2007b.

Kulmala, M., Korhonen, P., Laaksonen, A., and Vesala, T.: Changes in cloud properties due to NOx emissions, Geophys. Res. Lett., 22, 239-242, 1995.

Kulmala, M., Toivonen, A., Mattila, T., and Korhonen, P.: Variations of cloud droplet concentrations and the optical properties of clouds due to changing hygroscopicity: A model study, J. Geophys. Res., 103, 16 183-16 195, 1998.

Liao, H. and Seinfeld, J. H.: Global impacts of gas-phase chemistry-aerosol interactions on direct radiative forcing by anthropogenic aerosols and ozone, J. Geophys. Res., 110, D18208, doi:10.1029/2005JD005907, 2005. 
Liao, H., Adams, P. J., Chung, S. H., Seinfeld, J. H., Mickley, L. J., and Jacob, D. J.: Interactions between tropospheric chemistry and aerosols in a unified general circulation model, J. Geophys. Res., 108, 4001, doi:10.1029/2001JD001260, 2003.

Liao, H., Seinfeld, J. H., Adams, P. J., and Mickley, L. J.: Gloabal radiative forcing of coupled tropospheric ozone and aerosols in a unified general circulation model, J. Geophys. Res., 109, D16207, doi:10.1029/2003JD004456, 2004.

Liao, H., Chen, W.-T., and Seinfeld, J. H.: Role of climate change in global predictions of future tropospheric ozone and aerosols, J. Geophys. Res., 111, D12304, doi:10.1029/2005JD006852, 2006.

Martin, S. T., Hung, H.-M., Park, R. J., Jacob, D. J., Spurr, R. D., Chance, K., and Chin, M.: Effects of the physical state of tropospheric ammonium-sulfate-nirate particles on global aerosol direct radiative forcing, Atmos. Chem. Phys., 4, 183-214, 2004, http://www.atmos-chem-phys.net/4/183/2004/.

Meng, Z. Y., Seinfeld, J. H., Saxena, P., and Kim, Y. P.: Atmospheric gas-aerosol equilibrium IV. thermodynamics of carbonates, J. Atmos. Sci. Techn., 23, 131-154, 1995.

Metzger, S. and Lelieveld, J.: Reformulating atmospheric aerosol thermodynamics and hygroscopic growth into haze and clouds, Atmos. Chem. Phys., 7, 3163-3193, 2007, http://www.atmos-chem-phys.net/7/3163/2007/.

Metzger, S., Mihalopoulos, N., and Lelieveld, J.: Importance of mineral cations and organics in gas-aerosol partitioning of reactive nitrogen compounds: case study based on MINOS results, Atmos. Chem. Phys., 6, 2549-2567, 2006, http://www.atmos-chem-phys.net/6/2549/2006/.

Metzger, S. M., Dentener, F. J., Jeuken, A., Krol, M., and Lelieveld, J.: Gas/aerosol partitioning 2: Global model results, J. Geophys. Res., 107(D16), 4313, doi:10.1029/2001JD001103, 2002a.

Metzger, S. M., Dentener, F. J., Lelieveld, J., and Pandis, S. N.: Gas/aerosol partitioning 1: A computationally efficient model, J. Geophys. Res., 107(D16), 4312, doi:10.1029/2001JD001102, 2002b.

Miller, R. L., Cakmur, R., Perlwitz, J., Geogdzhayev, I., Ginoux, P., Kohfeld, K., Koch, D., Prigent, C., Ruedy, R., Schmidt, G., and Tegen, I.: Mineral dust aerosols in the NASA Goddard Institute for Space Sciences ModelE atmospheric general circulation model, J. Geophys. Res., 111, D06208, doi:10.1029/2005JD005796, 2006.

Myhre, G., Grini, A., and Metzger, S.: Modelling of nitrate and ammonium-containing aerosols in presence of sea salt, Atmos. Chem. Phys., 6, 4809-4821, 2006,

http://www.atmos-chem-phys.net/6/4809/2006/.

Nakicenovic, N., Alcamo, J., and Davis, G.: Special Report on Emission Scenarios, Cambridge University Press, edited by: Nakicenovic, N. and Swart, R., New York, 2000.

Nenes, A., Pilinis, C., and Pandis, S. N.: Isorropia: A new thermodynamic model for multiphase multicomponent inorganic aerosols, Aquat. Geochem., 4(1), 123-152, 1998.

Olivier, J. and Berdowski, J.: Global emissions sources and sinks, chap. The climate System, pp. 33-78, ISBN 9058092550 , Swets and Zeitlinger Publishers, Lisse, The Netherlands, 2001.

Pilinis, C. and Seinfeld, J. H.: Continued development of a general equilibrium model for inorganic multicomponent atmospheric aerosols, Atmos. Environ., 21(11), 2453-2466, 1987.

Pilinis, C., Capaldo, K. P., Nenes, A., and Pandis, S. N.: MADMA new multicomponent aerosol dynamics model, Aerosol Sci.
Technol., 32(5), 482-502, 2000.

Price, C., Penner, J., and Prather, M.: NOx from lightning: 1. Global distribution based on lightning physics, J. Geophys. Res., 102, 5929-5941, 1997.

Prospero, J. M.: The atmospheric transport of particles to the ocean, SCOPE report: Particle flux into the ocean, edited by: Ittekkot, V., Honjo, S., Depertris, P. J., Wiley, New York, NY, 1995.

Raper, J. L., Kleb, M., Jacob, D., et al.: Pacific Exploratory Mission in the tropical Pacific: PEM-Tropics B, MarchApril 1999, J. Geophys. Res., 106(D23), 32 401-32 426, doi:10.1029/2000JD900833, 2001.

Rodriguez, M. A. and Dabdub, D.: IMAGES-SCAPE2: A modeling study of size and chemically resolved aerosol thermodynamics in a global chemical transport model, J. Geophys. Res, 109, D02203, doi:10.1029/2003JD003639, 2004.

Russell, G., Miller, J., Rind, D., Ruedy, R., Schmidt, G., and Sheth, S.: Comparison of model and observed regional temperature changes during the past 40 years., J. Geophys. Res., 105, $14891-$ $14898,2000$.

Saxena, P., Seigneur, C., and Seinfeld, J. H.: A comparative study of equilibrium approaches to the chemical characterization of secondary aerosols, Atmos. Environ., 20, 1471-1483, 1986.

Schmidt, G. A., Ruedy, R., Hansen, J., Aleinov, I., Bell, N., Bauer, M., Bauer, S., Cairns, B., Cheng, Y., DelGenio, A., Faluvegi, G., Friend, A., Hall, T. M., Hu, Y., Kelley, M., Kiang, N., Koch, D., Lacis, A. A., Lerner, J., Lo, K. K., Miller, R. L., Nazarenko, L., Oinas, V., Perlwitz, J., Perlwitz, J., Rind, D., Romanou, A., Russell, G. L., Shindell, D. T., Stone, P. H., Sun, S., Tausnev, N., and Yao, M.-S.: Present day atmospheric simulations using GISS ModelE: Comparison to in-situ, satellite and reanalysis data, J. Climate, 19, 153-192, 2006.

Schulz, M., Textor, C., Kinne, S., Balkanski, Y., Bauer, S., Berntsen, T., Berglen, T., Boucher, O., Dentener, F., Guibert, S., Isaksen, I., Iversen, T., Koch, D., Kirkevg, A., Liu, X., Montanaro, V., Myhre, G., Penner, J., Pitari, G., Reddy, S., Seland, ., Stier, P., and Takemura, T.: Radiative forcing by aerosols as derived from the AeroCom present-day and pre-industrial simulations., Atmos. Chem. Phys., 6, 5225-5246, 2006, http://www.atmos-chem-phys.net/6/5225/2006/.

Shindell, D., Faluvegi, G., Stevenson, D., Krol, M., Emmons, L., Lamarque, J.-F., Ptron, G., Dentener, F., Ellingsen, K., Schultz, M., Wild, O., Amann, M., Atherton, C., Bergmann, D., Bey, I., Butler, T., Cofala, J., Collins, W., Derwent, R., Doherty, R., Drevet, J., Eskes, H., Fiore, A., Gauss, M., Hauglustaine, D., Horowitz, L., Isaksen, I., Lawrence, M., Montanaro, V., Mller, J.-F., Pitari, G., Prather, M., Pyle, J., Rast, S., Rodriguez, J. M., Sanderson, M., Savage, N., Strahan, S., Sudo, K., Szopa, S., Unger, N., van Noije, T., and Zeng, G.: Multi-model simulations of carbon monoxide: Comparison with observations and projected near-future changes, J. Geophys. Res., 111, D19306, doi:10.1029/2006JD007100, 2006.

Shindell, D. T., Faluvegi, G., and Bell, N.: Preindustrial-to-presentday radiative forcing by tropospheric ozone from improved simulations with the GISS chemistry-climate GCM, Atmos. Chem. Phys., 3, 1675-1702, 2003, http://www.atmos-chem-phys.net/3/1675/2003/.

Singh, H., Brune, W., Crawford, J., et al.: Overview of the summer 2004 intercontinental chemical transport experiment - North America (INTEX-A), J. Geophys. Res., D24S01, 
doi:10.1029/2006JD007905, 2006.

Streets, D. G., Bond, T. C., Lee, T., and Jang, C.: On the future of carbonaceous aerosol emissions., J. Geophys. Res, 109, D24212, doi:10.1029/2004JD004902, 2004.

Textor, C., Schulz, M., Guibert, S., Kinne, S., Bauer, S., Balkanski, Y., Berntsen, T., Berglen, T., Boucher, O., Chin, M., Dentener, F., Diehl, T., Feichter, H., Fillmore, D., Ghan, S., Ginoux, P., Gong, S., Grini, A., Hendricks, J., Horrowitz, L., Isaksen, I., Iversen, T., Kirkevag, A., Koch, D., Kristjansson, J., Krol, M., Lauer, A., Lamarque, J., Liu, X., Montanaro, V., Myhre, G., Penner, J., Pitari, G., Reddy, S., Seland, O., Stier, P., and T. Takemura, $\mathrm{X}$. T.: Analysis and quantification of the diversities of aerosol life cycles within AeroCom, Atmos. Chem. Phys., 6, 1777-1813, 2006,

http://www.atmos-chem-phys.net/6/1777/2006/.

Topping, D. O., Figgans, G. B. M., and Coe, H.: A curved multicomponent aerosol hygroscopicity model framework: Part 1 -inorganic compounds, Atmos. Chem. Phys., 5, 1205-1222, 2005a.

Topping, D. O., McFiggans, G. B., and Coe, H.: A curved multicomponent aerosol hygroscopicity model framework: Part 2 : Including organic compounds, Atmos. Chem. Phys., 5, 1223$1242,2005 b$.
Trebs, I., Metzger, S., Meixner, F. X., Helas, G., Hoffer, A., Rudich, Y., Falkovich, A. H., Moura, M. A. L., da Silva Jr., R. S., Artaxo, P., Slanina, J., and Andreae, M. O.: The $\mathrm{NH}_{4}^{+}-\mathrm{NO}_{3}^{-}-\mathrm{Cl}^{-}-\mathrm{SO}_{4}^{2-}-\mathrm{H}_{2} \mathrm{O}$ aerosol system and its gas phase precursors at a pasture 585 site in the amazon basin: How relevant are mineral cations and soluble organic acids?, J. Geophys. Res., 110, D07303, doi:10.1029/2004JD005478.587, 2005.

Unger, N., Shindell, D. T., Koch, D., Amann, M., Cofala, J., and Streets, D.: Influences of man-made emissions and climate changes on tropospheric ozone, methane and sulfate at 2030 from a broad range of possible futures, J. Geophys. Res., 111, D12313, doi:10.1029/2005JD006518, 2006.

Zaveri, R. A., Easter, R. C., and Wexler, A. S.: A new method for multicomponent activity coefficients of electrolytes in aqueous atmospheric aerosols, J. Geophys. Res., 110, D24203, doi:10.1029/2004JD004681.602, 2005.

Zhang, Y., Seigneur, C., Seinfeld, J. H., Jacobson, M., Clegg, S. L., and Binkowski, F. S.: A comparative review of inorganic aerosol thermodynamic equilibrium modules: similarities, differences, and their likely causes, Atmos. Environ., 34(1), 117-137, 2000. 